OPEN ACCESS

Edited by:

Iris Eline Hendriks,

University of the Balearic

Islands, Spain

Reviewed by:

Luis G. Egea,

University of Cádiz, Spain

Gema Hernan,

Florida State University, United States

${ }^{*}$ Correspondence:

Rohani Ambo-Rappe

rohani.amborappe@gmail.com

Specialty section:

This article was submitted to Global Change and the Future Ocean,

a section of the journal

Frontiers in Marine Science

Received: 07 December 2019

Accepted: 21 April 2020

Published: 15 May 2020

Citation:

Artika SR, Ambo-Rappe $R$

Teichberg M, Moreira-Saporiti A and Viana IG (2020) Morphological and Physiological Responses of Enhalus acoroides Seedlings Under Varying Temperature and Nutrient Treatment.

Front. Mar. Sci. 7:325

doi: 10.3389/fmars.2020.00325

\section{Morphological and Physiological Responses of Enhalus acoroides Seedlings Under Varying Temperature and Nutrient Treatment}

\author{
Suci Rahmadani Artika ${ }^{1}$, Rohani Ambo-Rappe ${ }^{1 *}$, Mirta Teichberg ${ }^{2}$, \\ Agustín Moreira-Saporiti ${ }^{2,3}$ and Inés G. Viana ${ }^{2,4}$ \\ ${ }^{1}$ Department of Marine Science, Faculty of Marine Science and Fisheries, Hasanuddin University, Makassar, Indonesia, \\ ${ }^{2}$ Leibniz Centre for Tropical Marine Research GmbH, Bremen, Germany, ${ }^{3}$ Faculty of Biology and Chemistry, University of \\ Bremen, Bremen, Germany, ${ }^{4}$ Department of Ecology and Animal Biology, University of Vigo, Vigo, Spain
}

Seagrass meadows are declining globally. In Indonesia, 75\% loss has been reported in the last 5 years. The decrease of the seagrass area is influenced by the simultaneous occurrence of many factors at the local and global scale, including nutrient enrichment and climate change. This study aims to find out how increasing temperature and nutrient enrichment affect the morphological, biochemical and physiological responses of Enhalus acoroides in the seedling phase, which has not previously been studied. To achieve these aims, a laboratory experiment of combined temperature and nutrient treatments was conducted using recently-germinated seedlings of $E$. acoroides. The results showed that the seedlings were tolerant to an extended exposure to the current ambient maximum temperature. Under higher temperature treatment, the seedlings were observed to increase in aboveground size traits (e.g., number of leaves, leaf length, biomass, and leaf area), as well as in belowground traits, such as root length. The results in this study also showed that the initial seed size matters for morphological responses. On the contrary, nutrient responses of seedlings were practically absent, suggesting they could rely on internal reserves. Interaction between both factors was limited, with the exception of low temperature and high nutrient treatment, in which the AG:BG ratio and leaf elongation rate increased. Fluorescence parameters were not influenced by any of the water treatments. The results in this study suggest that $E$. acoroides seedlings rely energetically in the reserves within the seedling and that increasing temperature might result in faster seedling development, although no interactions with other organisms were tested. This is of importance when studying the resilience capacity of this species and when restoration attempts are planned, as a faster root development would provide a faster stabilization in the sediment and the survival of the whole plant.

Keywords: tropical seagrass, Indo-Pacific, traits, growth, nutrient content, photosynthesis, carbohydrates, Indonesia 


\section{INTRODUCTION}

Seagrasses are marine flowering plants that are globally distributed and can form dense meadows in shallow water coastal environments (Duarte, 1991, 2001; Duarte and Cebrián, 1996; Short et al., 2007). They are key ecosystem engineers and the only submerged marine species with both above(AG) and below-ground (BG) tissues that sustain multiple ecosystem services and functions. Seagrasses fuel food webs by supplying a combination of food and shelter to various macro flora and fauna, including commercially important fish species, sustain high rates of primary production, filter coastal waters by capturing particles and dissolved nutrients, participate in nutrient cycling, and provide coastal protection by attenuating waves and stabilizing sediments by their singular BG tissues (Hemminga et al., 1991; Duarte and Cebrián, 1996; Hemminga and Duarte, 2000; Duarte, 2001; Cullen-Unsworth and Unsworth, 2013; Tuya et al., 2014; Weitzman et al., 2015). Seagrass meadows also help to mitigate climate change by the capture and storage of organic carbon ("blue carbon"), reducing $\mathrm{CO}_{2}$ concentrations in seawater (Fourqurean et al., 2012; Macreadie et al., 2019). Despite their global significance the attention paid to seagrass meadows is much lower than other coastal ecosystems (Cullen-Unsworth et al., 2014).

Seagrasses are also one of the most threatened ecosystems due to their presence in coastal areas (Orth et al., 2006; Burkholder et al., 2007), where they are declining globally, with a loss of 29\% from 1876 to 2006 (Waycott et al., 2009). Many factors have been identified as the reason for this decrease, both at the local and global scale, including nutrient enrichment and climate change (Orth et al., 2006; Waycott et al., 2009). Regional losses may be even higher in the tropics, such as in Indonesia, where $75 \%$ loss has been reported in the last 5 years (Unsworth et al., 2018). Tropical ecosystems are biodiversity hotspots, with the tropical Indo-Pacific bioregion hosting 24 of the approximately 60 seagrass species (Short et al., 2007). As seagrass traits and functions sustaining different ecosystem services and the stressors that affect them are species-specific, multi-specific assemblages have a greater probability of containing a greater functional diversity, but also greater losses (Duarte, 2000).

Human development and associated activities (e.g., agriculture, fish and seaweed aquaculture) have triggered land use changes and urbanization which have led to an increase in the concentration of nutrients and sediments into the coastal waters. This nutrient increment exceeds the nutrient cycling capacity of the system, increasing the organic carbon supply, and ultimately leading to eutrophication processes that are characterized by algal blooms, epiphyte growth, anoxic conditions in the sediments and, eventually, biodiversity loss and seagrass death (Lee et al., 2006; Khan and Mohammad, 2014). The effects of nutrient enrichment depend on species-specific features, such as nutrient uptake capacity, the level of nutrient surplus that can vary from moderate to severe, and on local physical conditions, such as currents and tides. Eutrophication has been identified as one of the most important factors affecting productivity, community carbon dynamics, and seagrass growth, and is one of the major threats confronting coastal ecosystems. Direct effects occur through stability of physiological mechanisms (Burkholder et al., 1992; Bird et al., 1998; Brun et al., 2002; Invers et al., 2004; Touchette and Burkholder, 2007) causing increased nutrient uptake ability (Viana et al., 2019), nutrient imbalance (Li et al., 2019), changes in morphological indices (Mvungi and Pillay, 2019), changes in growth (Terrados et al., 1999a), changes in sexual reproduction (Duarte et al., 1997), or direct ammonium toxicity (Van Katwijk et al., 1997). Indirect effects of nutrient inputs occur through blooming algae which cause light depletion or nutrient competition (Duarte, 1995; Short et al., 1995; Moore and Wetzel, 2000; Nixon et al., 2001; Burkholder et al., 2007), through the ecological role of herbivores due to modifications in palatability and plant defenses against herbivory (Tomás et al., 2015; Jiménez-Ramos et al., 2017; Marco-Méndez et al., 2017; Campbell et al., 2018; Hernán et al., 2019), or through oxygen depletion in sediments (Terrados et al., 1999b). Therefore, the effects of nutrients on seagrass responses range from no impacts to positive or negative impacts. Tropical systems are oligotrophic and naturally nutrient limited; therefore, even small amounts of nutrient additions might rapidly increase competence among primary producers.

Climate change may also impact seagrasses due to rising mean water temperatures and more frequent and lengthy heat waves (Marbà et al., 1996; Short and Wyllie-Echeverria, 1996). Impacts of temperature increase can be detected at the plant level and have been found to benefit the growth, biomass (Masini et al., 2001), flowering (Diaz-Almela et al., 2007), or photosynthetic rates (Campbell et al., 2006) of several seagrass species. But if elevated temperature rises above a threshold, or persist for longer periods of time, effects could be detrimental and result in community structure damages by causing impacts on seagrass metabolism and nutrient uptake ability (Lee et al., 2007; Moore and Short, 2007; Collier and Waycott, 2014). This can eventually lead to die off if extreme temperatures persist (Cambridge et al., 1986; Bulthuis, 1987; Short and Neckles, 1999; York et al., 2013). Recent experiments suggest that heat waves may enhance the autotrophic metabolism of seagrass communities in contrast to other previous research suggesting solely negative effects (Egea et al., 2019). Therefore, temperature is of crucial importance in determining seagrass metabolism, growth and survival. While climate change has not yet significantly impacted seagrass areas in Indonesia (Unsworth et al., 2018), it is essential to take in consideration that tropical seagrasses are growing closer to their photosynthetic and physiological limits in comparison to temperate seagrasses, making them highly vulnerable to rising temperature thresholds caused by climate warming (Tewksbury et al., 2008).

The ecosystem functions performed by seagrasses are consequences of their physiological, biochemical and morphological traits. Therefore, even though changes in seagrass traits could be seen as positive for individual seagrass plants (i.e., increasing growth or photosynthetic rate), it could also lead to changes in their functions and imbalances in their biotic and abiotic interactions, negatively affecting the ecosystem services they perform. For example, it could lead to changes in hydrodynamic conditions or sedimentation rates (Fonseca et al., 2019) which affect the distribution of organisms within the 
canopies, and therefore, biodiversity (González-Ortiz et al., 2014; Jiménez et al., 2019; Meysick et al., 2019). Seagrass responses to changes in nutrient and temperature conditions can be measured by changes in their trait values which are often used as indicators of environmental stress in coastal management. Different traits have been identified as indicators of seagrass stress such as nutrient inputs, temperature or shading (Lee et al., 2007; Martínez-Crego et al., 2008; De los Santos et al., 2016; Roca et al., 2016). But seagrass plants are rarely affected by just one variable and identifying the effect of single stressors is a challenge in natural seagrass meadows. The interaction between stressors is now viewed as a crucial issue, and it is suggested that singlefactor experiments are not adequate for assessing the effects of several disturbances on coastal marine ecosystems (Wernberg et al., 2012; Todgham and Stillman, 2013; Ontoria et al., 2019). In this way, laboratory experiments under controlled conditions might help to isolate the effects on plant trait variability of single and multiple stressors. These physiological experiments are also needed in order to make predictions about seagrass resilience or tolerance to future climate scenarios. The combined impacts of rising temperature and increased nutrient loading has been studied in adult species of Zostera spp. and Cymodocea nodosa (Touchette and Burkholder, 2002; Touchette et al., 2003; Kaldy, 2014; Jiménez-Ramos et al., 2017; Mvungi and Pillay, 2019; Ontoria et al., 2019), but, as far as we know, no studies were carried out in seagrass early life stages. There are few works on the combined effects of other stressors in seagrass seedlings but none in tropical species (Hernán et al., 2016; Alexandre et al., 2018; Pereda-Briones et al., 2018, 2019; Yue et al., 2019).

Enhalus acoroides is a tropical seagrass with a high tolerance to environmental changes such as temperature and nutrients (McMillan, 1984; Terrados et al., 1999a), and therefore, changes in its morphological, biochemical or physiological traits can be used as indicators to increasing temperature and varying nutrient fluctuations. E. acoroides is also an ecosystem engineer which, by altering the physical and chemical properties of the environment, can facilitate the presence of species that otherwise would be absent. The opportunity of colonizing new habitats and the genetic diversity provided by sexual reproduction could make seagrass populations more resistant to the current changing scenario. In addition, due to the highly variable flower production and low success of seedling establishment, sexual reproduction and seedling stages are critical phases in the life of seagrasses (Bewley and Black, 1994; Schupp, 1995; Peterson and Baldwin, 2004). However, there is a lack of research conducted on E. acoroides seeds and seedlings in order to understand their response to various environmental changes. This is of importance as seagrass restoration programs could be based on adult seagrass transplantation or on generative techniques. Planting seedlings is a cost-efficient method for large-scale seagrass meadow restoration. However, the main limitation of seedling establishment programs is the low seedling survival rate observed due to unsuitability of environmental conditions (Ambo-Rappe et al., 2019). Therefore, the study of seedling trait responses under different environmental conditions, such as temperature or nutrient enrichment, on this early-life phase may enhance future restoration and conservation management plans of these threatened ecosystems.

This study aims to assess the morphological, physiological and biochemical trait responses of the seedling stage of E. acoroides to increased temperature and nutrient enrichment. Furthermore, the results of this study will provide important information and serve as a reference to predict the effects of temperature changes, as a proxy for climate change conditions, and nutrient enhancement on seagrass survival. To achieve these aims, a laboratory experiment was conducted using seedlings of $E$. acoroides under the combination of increased temperature and nutrient enrichment. We hypothesized that seedlings of $E$. acoroides might be tolerant to rising temperatures and that nutrient enrichment would increase their growth performance, causing synergetic effects under higher temperature.

\section{MATERIALS AND METHODS Collection and Maintenance of Seagrass Seeds}

Fruits of E. acoroides were collected on mid-January 2017 on the southwest side of Barrang Lompo Island, South Sulawesi, Indonesia (S 503’05, E 119 $19^{\prime} 37$ ), where E. acoroides is abundant at a depth range of $1-3 \mathrm{~m}$. Highest nitrate concentrations in the area range between 0.1 and $0.6 \mu \mathrm{M}$, while phosphate concentrations range between 0.12 and $0.14 \mu \mathrm{M}$ (Kegler et al., 2018). Annual temperature range in the dry season varies in this area between 26 and $32^{\circ} \mathrm{C}$ (Teichberg et al., 2018). During seed collection, we measured $28-32^{\circ} \mathrm{C}$ during mid-day. The ripe seagrass fruit was opened, packed in a Styrofoam box with wet breathable polyester fiber sheets, and then transported to the Marine Experimental facilities (MAREE) at the Leibniz Centre for Tropical Marine Research (ZMT) in Bremen (Germany) in $<24 \mathrm{~h}$. Once at the MAREE, seeds were planted directly in polypropylene trays previously filled with silicate sediment of at least $10 \mathrm{~cm}$ depth.

All trays with seeds were kept in 250-1 aquaria filled with low nutrient artificial sea water (ASW) (Red Sea Salt, Red Sea Europe Company) under controlled conditions of light irradiance (200 $\pm 30 \mu \mathrm{mol}$ photons $\left.\mathrm{m}^{-2} \mathrm{~s}^{-1}\right)$, temperature $\left(26 \pm 1^{\circ} \mathrm{C}\right)$ and salinity (35 PSU) for a 1 week acclimation phase until the root and some leaf growth was observed (at which point they entered the seedling stage). The photoperiod of the fluorescent lights was 12:12 h light:dark cycle.

\section{Experimental Design and Setup}

We conducted a full-factorial experiment combining two water temperatures $\left(26\right.$ and $31^{\circ} \mathrm{C}$ ) representing the minimum and maximum temperatures within the home region that seagrasses are currently exposed to, and two nutrient treatments (low nutrient concentrations of $2 \mu \mathrm{M}$ of $\mathrm{NH}_{4} \mathrm{NO}_{3}$ and $0.1 \mu \mathrm{M}$ $\mathrm{KH}_{2} \mathrm{PO}_{4}$ and high nutrient concentrations of $20 \mu \mathrm{M}$ of and $1 \mu \mathrm{M}$ of $\mathrm{NH}_{4} \mathrm{NO}_{3}$ and $\mathrm{KH}_{2} \mathrm{PO}_{4}$ ). This yielded in 4 experimental treatments: low temperature and low nutrient concentrations, low temperature and high nutrient concentrations, high temperature and low nutrient concentrations, and high temperature and high nutrient concentrations. The experiment 
was conducted under laboratory conditions in an indoor flow-through system at the MAREE (ZMT, Bremen) with 24 individual aquaria with $29 \times 13 \times 30 \mathrm{~cm}$ dimensions and $10 \mathrm{l}$ volume (Figure 1A). Seedlings (consisting of visible cotyledon, seeds and no roots at the beginning of the experiment) were categorized as small (diameter between 0.6 and $1.0 \mathrm{~cm}$ ), medium (diameter between 1.1 and $1.5 \mathrm{~cm}$ ) and large (diameter between 1.6 and $1.7 \mathrm{~cm}$ ). One seedling of each size was distributed in each aquarium, making a total of three seedlings per aquarium. The aquaria additionally contained adult seagrasses from 3 different species (Viana et al., in prep).

The target temperature values were obtained by placing aquaria in larger experimental tanks (ETs) of 2501 that acted as water baths maintaining a constant water temperature. Six aquaria were placed in 4 different ETs following a split-plot experimental design with nutrient treatments nested within the 4 ETs set at the two temperatures (Figure 1A). There was no interaction between aquaria that acted as replicates $(n=6)$. Water temperature was controlled in each ET by using heaters (EHEIM) connected to an individual electronic system that was continuously regulating the temperature of the water bath by digital controllers and individual temperature probes $\left( \pm 0.2^{\circ} \mathrm{C}\right)$. Air pumps were also placed in each ET to ensure water movement of the water bath. The light was provided by LED lamps (Hydra Fifty-two HD, Aqualllumination ${ }^{\circledR}$, Iowa), 2 lamps were placed at the same height at the top part of each ET, providing 200 $\pm 20 \mu \mathrm{mol} \mathrm{m} \mathrm{m}^{-2} \mathrm{~s}^{-1}$ of light (measured at each aquarium to ensure homogeneous irradiance). Light was set on a 12:12 h light:dark photoperiod with sunrise and sunset simulation. Transparent PVC lids were placed on each ET to reduce water evaporation.

High and low nutrient ASW solutions were individually supplied to each of the 24 aquaria from two different water reservoirs of $\sim 1151$ each, with either high or low nutrient concentrations using a 24-channel peristaltic pump (ISMATEC, Germany). The flow from both water reservoirs was maintained at a constant rate at $\sim 5.81 \mathrm{~d}^{-1}$ ensuring total water renovation inside each aquarium every $\sim 1.5$ days. Water reservoirs were manually emptied from any remaining water and refilled with fresh ASW every other day. Nutrients to the water reservoirs were added in a previously dissolved form from stock solutions of $\mathrm{NH}_{4} \mathrm{NO}_{3}$ and $\mathrm{KH}_{2} \mathrm{PO}_{4}$ (Merck, Germany). Once in the water reservoir, ASW was gently mixed and an air pump was placed in each water reservoir to ensure further aeration and mixing. Air pumps were placed in each aquarium to ensure water aeration and mixing by moving water from the bottom to the top. Water constantly overflowed from the aquaria to the water bath of the ETs ensuring water renewal. At the same time, ETs were drained of the surplus water flowing out of the aquaria. Algae were removed from the blades of the plants throughout the experiment but not from the rest of the aquaria.

For the experiment to begin, the temperature was increased in 2 random ETs from 26 to $31^{\circ} \mathrm{C}$ at $1^{\circ} \mathrm{C} \mathrm{d}^{-1}$ while the other 2 ETs remained at the initial temperature of $26^{\circ} \mathrm{C}$. Once the desired temperatures were stable in all ETs, the nutrient enrichment began. From that moment, the experiment lasted for approximately 1 month (January 20th to February 22nd, 2017).

\section{Water Sampling}

Water parameters, including $\mathrm{pH}$, temperature and salinity, were monitored three times per week during the treatment phase with a multi parameter probe (WTW Multiprobe). During the experiment the temperature inside aquaria was also continuously monitored by Hobo loggers (Onset, MA, USA) placed in one random aquarium of each ET $(n=4)$. Water samples were taken every week from the two water reservoirs and random aquaria of each treatment ( $n=4$ each week) for DIN (dissolved inorganic nitrogen, $\mathrm{NH}_{4}^{+}, \mathrm{NO}_{\mathrm{x}}^{-}$and $\mathrm{NO}_{2}^{-}$); silicate and phosphate. Water samples were sampled with a syringe, immediately filtered $(0.45 \mu \mathrm{m}$ pore size $)$ in pre-rinsed polyethylene bottles and frozen $\left(-20^{\circ} \mathrm{C}\right)$. Analysis was performed using a continuous flow injection analyzing system (Skalar SAN++-System) following Grasshoff et al. (1999).

At the end of the experiment, water samples from all aquaria were collected and immediately filtered for chlorophyll $a$ and $b$ (Chl- $a$ and $-b$ ) measurement. Water was filtered under constant pressure onto pre-combusted $\left(5 \mathrm{~h}, 450^{\circ} \mathrm{C}\right)$ Whatman GF/F filters. Filters for Chl- $a$ and $-b$ analysis were stored at $-20^{\circ} \mathrm{C}$. Pigments were extracted from the filters in $8 \mathrm{ml}$ of $96 \%$ ethanol in glass vials placed for $5 \mathrm{~min}$ at $80^{\circ} \mathrm{C}$ and subsequently placed in a rotor at room temperature in the dark for approximately $24 \mathrm{~h}$. Extracts were subsequently centrifuged at 5,000 rpm for $20 \mathrm{~min}$. Chl- $a$ and - $b$ samples were determined in a photometer Shimadzu UV-1700.

\section{Seedlings Morphological and Physiological Traits}

At the end of the experiment, seedlings were removed from the aquaria and the morphological measurements on each plant were first performed. Afterwards, plants were carefully separated with a glass slide into the different parts: leaves (for fluorescence measurements and nutrient content), seeds and roots (for nutrient content). While morphological and fluorescence measurements were individually performed on the three seedlings, the nutrient content was analyzed in the pooled material of the three seedlings from each aquarium. Samples of the separated plant were gently cleaned with distilled water to remove any sediment or epiphytes and subsequently frozen at $-80^{\circ} \mathrm{C}$ until analysis.

\section{Morphological Traits}

Seagrass morphological traits were determined by measuring the length, width and number of leaves per seedling, the length and number of roots, the height and diameter of seeds and the biomass of leaves, seeds and roots. AG (blades) and BG (roots) biomass was also determined $( \pm 0.01 \mathrm{~g})$.

\section{Growth Rates}

Seedling growth rate measurements were done using the leaf marking method (Short and Duarte, 2001). At the beginning of the experiment, leaves were perforated close to the seed using a pin. At the end of the experiment, the length from the seed to the mark of each leaf was measured. Leaf growth rates were obtained by dividing the elongation (distance from the base to the mark) with the number of days since the seagrass leaves 

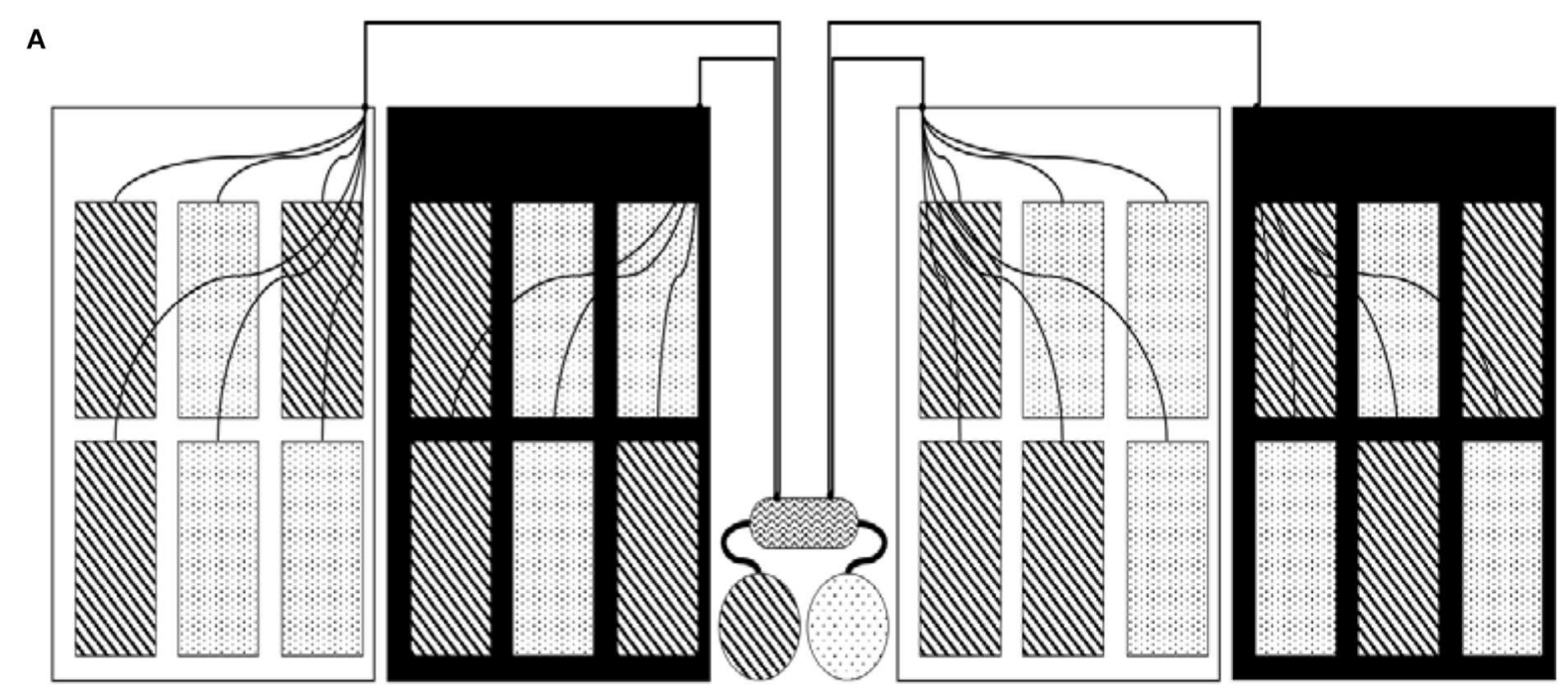

B

\section{Split-plot design with two blocking factors}

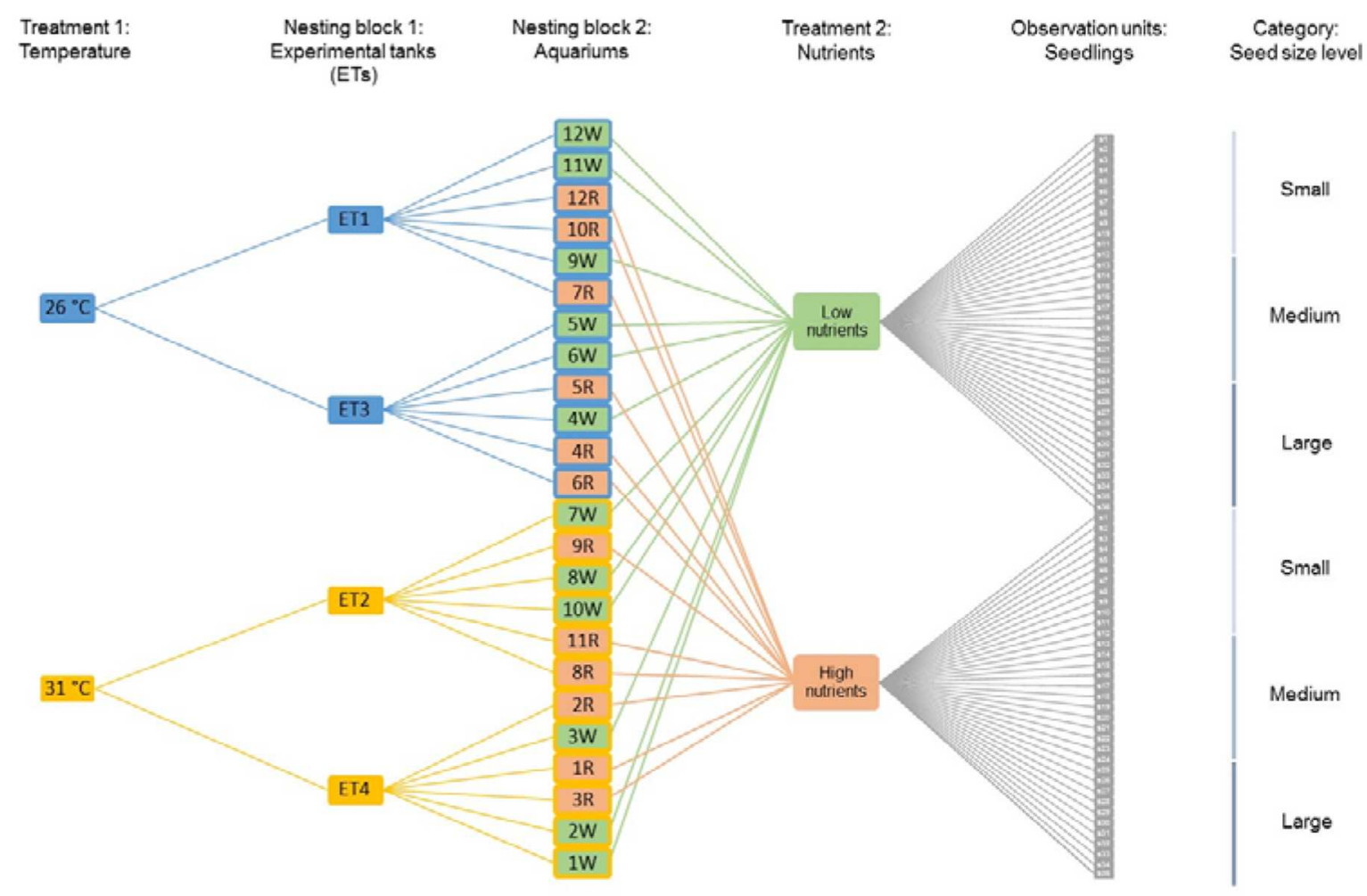

FIGURE 1 | (A) Nutrient and temperature split-plot experimental design. Artificial seawater was individually supplied to aquaria ( $n=24)$ from reservoirs with either high nutrient (dot boxes/circle) or low nutrient artificial seawater (strip boxes/circle) using a peristaltic pump. Six aquaria were placed in each experimental tank (ET) that acted as a water bath maintaining a constant temperature of either $26^{\circ} \mathrm{C}$ (white boxes) or $31^{\circ} \mathrm{C}$ (black boxes), with no interaction between aquaria that acted as replicates $(n=6)$. (B) Experimental split-plot design with two blocking factors. Temperature and nutrient treatments are the fixed effects (explanatory variables) in the model, and they are fully crossed (nutrient treatments are not nested by temperature treatments). Temperature, as it groups ETs and aquaria, is a group level predictor. Nutrients, as it groups the observation units (seedlings) is a data level predictor. ET and aquaria are nesting variables, this means that ET nests the aquaria and the aquaria nests the observation units (seedlings). The seedlings are also further classified as large, medium and small. 
were marked. Surface area (SA) was calculated with the following Equation (1).

SA Growth rate $\left(\mathrm{cm}^{2} d^{-1}\right)=\frac{\text { distance from the base to the mark } \times \text { leaf width }}{\text { number of days }}(1)$

\section{Photosynthetic Performance}

A PAM-2500 (Walz, Germany) was used for the measurement of the fluorescence of the seagrass through rapid light curves (RLC). The optical cable of the PAM was attached with leaf clips to the second leaf of the seedling, above the meristem, and at $3 \mathrm{~mm}$ distance from the tissue. The leaves were dark adapted for $5 \mathrm{~min}$ before measurement.

The RLC consisted of 12 saturating light pulses (separated by $30 \mathrm{~s}$ intervals), increasing the photosynthetic active radiation (PAR) between pulses until 2,001 $\mu \mathrm{mol}$ photons $\mathrm{m}^{-2} \mathrm{~s}^{-1}$. From the data of the RLC, several parameters were calculated.

Light saturation coefficient (Ek) and the slope of the light limited part of the curve (Alpha) were calculated using the package Phytotools (Silsbe and Malkin, 2015) with the R software (R Core Team, 2019) following the model of Jassby and Platt (1976). The maximum light utilization efficiency or maximum quantum yield was calculated following Equation (2) (Genty et al., 1989).

$$
\text { Maximum quantum yield }=\frac{(F m-F o)}{F m}
$$

Where $\mathrm{F}_{\mathrm{m}}$ is the maximum dark-adapted fluorescence and $\mathrm{F}_{\mathrm{o}}$ is the minimum dark-adapted fluorescence. The relative electron transport rate (rETR) was calculated for each step of the curve following Equation (3) (Sakshaug et al., 1997).

$$
r E T R=\frac{F m^{\prime}-F^{\prime}}{F m^{\prime}} \times \frac{P A R}{2}
$$

Where Fm' is the light adapted maximum fluorescence and F' the fluorescence yield at a particular light level. From the rETR values, maximum rETR (rETRmax) was calculated as the inflection point of the fitted rETR curve.

\section{Nutrient Content}

Leaf, seed and root nitrogen $(\mathrm{N})$ and carbon $(\mathrm{C})$ content $(\% \mathrm{~N}$ and $\% \mathrm{C}$, respectively) was analyzed on previously dried $\left(60^{\circ} \mathrm{C}, 48 \mathrm{~h}\right)$ and powdered seagrass tissue samples. Aliquots of the samples were weighed into tin capsules using an analytical scale prior to analysis (Euro EA3000 Elemental Analyzer).

\section{Non-structural Carbohydrate (NSC) Content}

The concentrations of soluble sugars (sucrose) and starch were measured on leaf and seed material that was previously freezedried $(48 \mathrm{~h})$ and ground to a fine powder. Sucrose was extracted from plant tissue by heating $\left(80^{\circ} \mathrm{C}\right)$ in $95 \% \mathrm{EtOH}$. The ethanol extracts were subsequently evaporated bubbling the samples with $\mathrm{N}_{2}$, and the remaining residues were dissolved in deionized water for sucrose analysis. Starch was extracted during $24 \mathrm{~h}$ from the ethanol-insoluble residue in $0.1 \mathrm{~N} \mathrm{NaOH}$. The sucrose and starch concentrations were determined spectrophotometrically
(486 and $640 \mathrm{~nm}$, respectively) using an F200-Pro TECAN@ plate reader. Resorcinol and anthrone assays were used for sucrose and starch determination, respectively, and sucrose was used as the standard for the calibration curve (Yemm and Willis, 1954; Huber and Israel, 1982). Results were reported in glucose equivalents $\mathrm{g}^{-1} \mathrm{DW}$. Current testing of this method has shown that $\mathrm{NaOH}$ extracts both starch and cellulose which can confound the results. Regarding the sucrose determination, this method only determines ketoses (as fructose) so we are ignoring the other component of sucrose, glucose, underestimating the final concentrations (M. Birkicht, personal communication).

\section{Statistical Analysis}

The experiment followed a split-plot design with three nesting factors (Schielzeth and Nakagawa, 2013). The two main factors (temperature and nutrient treatments) had two levels each (26 and $31^{\circ} \mathrm{C}$, and low and high nutrient concentrations, respectively), which were fully crossed.

We used permutational multivariate analysis of variance (PERMANOVA) (Anderson et al., 2008) to analyze the data. The statistic to test the null hypothesis of no differences in the position of the group centroids in the space of the chosen dissimilarity measure is the pseudo F-statistic. The fixed effects in the model were temperature and nutrient treatments, the seedling size and their interactions, together with the nesting factors temperature, ET and Aquarium. Three seedlings were nested in each aquarium; six aquaria were nested in four ETs, and two ETs were nested within each temperature treatment. Seedlings, with 3 levels of sizes, were evenly distributed between aquaria (Figure 1B). Seedling size and Aquarium were not included as factors in the model for biochemical trait analysis because seedling samples within the same aquaria were pooled. Data was scouted for outliers, which were identified as data exceeding 1.5 times the interquartile range of variation of the dataset. Outliers were eliminated from the model when they did not allow for meeting the model assumptions. Afterwards, we calculated the dissimilarity matrix using the Euclidean dissimilarity measure for all continuous variables and the BrayCurtis dissimilarity measure for the count variable (number of leaves). The assumptions of exchangeability of permutable units and homogeneity of multivariate dispersion were tested before analysis. When the homogeneity of multivariate dispersions was not met, the data were transformed (square root, log or inverse) and the dissimilarity matrix was recalculated. Once the assumptions were met, the model selection was performed with the Akaike Information Criterion (AIC). The model with the lowest AIC was chosen with three extra rules: The nesting variables and seedling size, and the interaction Temperature* Nutrient treatment was never dropped from the model to avoid pseudo-replication and because it was part of the hypothesis, respectively. If the final model had no significant interaction with seedling size, these interactions were dropped for simplification. The statistical analysis in the variable number of roots could not be performed due to presence of zeros in the data, which does not allow for the calculation of the BrayCurtis dissimilarity matrix. Starch concentration in seeds was not analyzed as homogeneity of multivariate dispersion assumptions 
could not be met. Water parameters (DIN, phosphate, and Chl$a$ and $-b$ ) and temperature in aquaria were compared using PERMANOVA, while DIN and phosphate concentrations in water reservoirs were analyzed using a two-way ANOVA.

We used R software to perform the analysis ( $\mathrm{R}$ Core Team, 2019) with the adonis 2 function of the package "vegan" (Oksanen et al., 2019). Temperature, nutrient, seed size, their interactions and the nesting structure (Temperature:ET:Aquarium) were the fixed effects in the model. The permutational unit for the model was the aquarium with 999 permutations, which is the recommended minimum number to test at an alpha-level of 0.05 (Manly, 1997).

\section{RESULTS}

\section{Experimental Water Chemistry and Trophic Conditions Within the Aquaria}

Water temperature was nearly constant throughout the experiment and within the target temperatures (PERMANOVA, $P<0.01$ ) (Table 1). Nutrient concentrations in the two main water reservoirs that continuously provided ASW to the aquaria were within the target concentrations throughout the experiment and were significantly different between the nutrient treatments (two-way ANOVA, $P<0.001$ ). Once in the aquaria, however, nutrients were rapidly taken up resulting in low inorganic nutrient concentrations in all treatments regardless of the inputs (PERMANOVA, $P>0.05$ ). In fact, some of the concentrations measured were not included in the analysis as they were below the quantification limit. Chl- $a$ concentrations in the water column were higher in the high nutrient treatments (2.6-5.9 $\left.\mu \mathrm{g} \mathrm{l}^{-1}\right)$ than in the low nutrient treatments $\left(2-2.1 \mu \mathrm{g} \mathrm{l}^{-1}\right.$ ) and significantly higher in the high temperature and high nutrient treatment (5.91 $\mathrm{Mg} \mathrm{l}^{-1}$ ); Chl- $b$ concentrations also increased in the high temperature and high nutrient treatment although no significant concentrations were observed among treatments (PERMANOVA, $P>0.05$ ). Therefore, the different treatments effectively changed trophic conditions within aquaria, as indicated by the increased Chl- $a$ and Chl- $b$ concentrations, as well as other algal blooms which were observed in the high nutrient treatments. Although the abundance of these other microorganisms could not be quantified, they were observable by naked eye and could be felt as a slimy layer on the aquaria and some seagrass leaves. They also formed fluffy masses with a slimy feel which disintegrated when attempts were made to capture them. Therefore, even though nutrient concentration parameters in aquaria were low, other observable parameters suggested eutrophic conditions were occurring in the high nutrient treatments. These symptoms were especially noticeable when high nutrients were combined with high temperature, leading to a greater growth of epiphytic algae. The salinity, $\mathrm{pH}$ and silicate values were constant across all treatments.

\section{Seedling Traits}

Seagrass seedling morphological traits and biochemical and physiological traits are shown in Tables 2, 3. Results of the PERMANOVA analyses are shown in Tables 4, 5 for morphological and biochemcial and physiological traits respectively.

\section{Seedling Morphological Traits}

Seagrass seedling morphological traits showed a greater response to temperature changes with fewer traits affected by nutrient enrichment (Table 2). Leaf traits showed the greatest differences relative to root traits, especially under different temperature treatments (Table 4). The high temperature and low nutrient treatment had 5 leaves, while all other treatments had 4 leaves per seedling. Maximum leaf length was the highest in the high temperature treatments, particularly when combined with high nutrients. This also had an impact on leaf SA and AG biomass, although significant interactions were not observed. The only seed trait that was significantly influenced by temperature was the diameter. Seed height and biomass were not significantly affected by any of the treatments (Tables 2, 4).

All seedlings had two roots except for the low temperature and high nutrient treatment that just had one root (Table 2).

TABLE 1 | Experimental water quality parameters.

\begin{tabular}{|c|c|c|c|c|c|}
\hline & \multirow[b]{2}{*}{$n$} & \multicolumn{4}{|c|}{ Treatments } \\
\hline & & $26^{\circ} \mathrm{C}+$ Low nutrient & $31^{\circ} \mathrm{C}+$ Low nutrient & $26^{\circ} \mathrm{C}+$ High nutrient & $31^{\circ} \mathrm{C}+$ High nutrient \\
\hline $\operatorname{DIN}(\mu \mathrm{M})^{\mathrm{R}}$ & 4 & \multicolumn{2}{|c|}{$5.66 \pm 0.51$} & \multicolumn{2}{|c|}{$22.40 \pm 0.98$} \\
\hline $\mathrm{PO}_{4}^{-}(\mu \mathrm{M})^{\mathrm{R}}$ & 4 & \multicolumn{2}{|c|}{$0.19 \pm 0.01$} & \multicolumn{2}{|c|}{$1.01 \pm 0.04$} \\
\hline \multirow[t]{2}{*}{ Water temperature $\left({ }^{\circ} \mathrm{C}\right)$} & $25^{\star}$ & $26.25 \pm 0.05$ & $31.01 \pm 0.07$ & $26.28 \pm 0.03$ & $31.01 \pm 0.05$ \\
\hline & $3735^{\ddagger}$ & $26.47 \pm 0.003$ & $31.13 \pm 0.004$ & $26.22 \pm 0.004$ & $31.48 \pm 0.002$ \\
\hline Salinity & 25 & $35.43 \pm 0.12$ & $35.39 \pm 0.10$ & $35.33 \pm 0.07$ & $35.39 \pm 0.11$ \\
\hline $\mathrm{pH}$ & 12 & $8.47 \pm 0.02$ & $8.39 \pm 0.02$ & $8.67 \pm 0.03$ & $8.59 \pm 0.02$ \\
\hline $\mathrm{DIN}(\mu \mathrm{M})$ & $5-10$ & $0.62 \pm 0.33$ & $0.88 \pm 0.44$ & $0.64 \pm 0.31$ & $1.25 \pm 0.01$ \\
\hline $\mathrm{PO}_{4}^{-}(\mu \mathrm{M})$ & $5-10$ & $0.15 \pm 0.01$ & $0.14 \pm 0.02$ & $0.14 \pm 0.00$ & $0.14 \pm 0.01$ \\
\hline Si $(\mu M)$ & $5-10$ & $0.71 \pm 0.07$ & $1.15 \pm 0.22$ & $0.91 \pm 0.20$ & $0.85 \pm 0.06$ \\
\hline Chl-a $\left(\mu \mathrm{gl}^{-1}\right)$ & 24 & $2.07 \pm 0.53$ & $2.07 \pm 0.53$ & $2.59 \pm 0.98$ & $5.91 \pm 2.41$ \\
\hline Chl- $b\left(\mu \mathrm{g} \mathrm{I}^{-1}\right)$ & 24 & $0.36 \pm 0.07$ & $0.36 \pm 0.07$ & $0.42 \pm 0.18$ & $0.88 \pm 0.43$ \\
\hline
\end{tabular}

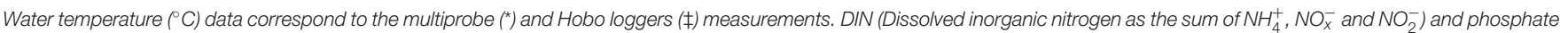
$\left(\mathrm{PO}_{4}^{-}\right)$concentrations in water reservoirs $(R)$ and random aquaria are shown. Values are given as means ( $\left.\pm S E\right)$. 
TABLE 2 | Morphological traits (mean \pm SE, $n=6$ ) of Enhalus acoroides seedlings in the four different temperature (Temp) and nutrient treatments at the end of the experiment.

\begin{tabular}{|c|c|c|c|}
\hline \multirow[t]{2}{*}{ Traits } & \multicolumn{3}{|c|}{ Treatments } \\
\hline & Temp & Low nutrient & High nutrient \\
\hline \multirow[t]{2}{*}{$N^{\circ}$ of leaves seedling ${ }^{-1}$} & $26^{\circ} \mathrm{C}$ & $4( \pm 0.13)$ & $4( \pm 0.31)$ \\
\hline & $31^{\circ} \mathrm{C}$ & $5( \pm 0.18)$ & $4( \pm 0.35)$ \\
\hline \multirow[t]{2}{*}{ Maximum leaf length (cm) } & $26^{\circ} \mathrm{C}$ & $1.79( \pm 0.17)$ & $1.97( \pm 0.25)$ \\
\hline & $31^{\circ} \mathrm{C}$ & $3.45( \pm 0.33)$ & $4.19( \pm 0.33)$ \\
\hline \multirow[t]{2}{*}{ Leaf width (cm) } & $26^{\circ} \mathrm{C}$ & $0.35( \pm 0.01)$ & $0.33( \pm 0.01)$ \\
\hline & $31^{\circ} \mathrm{C}$ & $0.38( \pm 0.03)$ & $0.37( \pm 0.01)$ \\
\hline \multirow[t]{2}{*}{ Leaf SA $\left(\mathrm{cm}^{2}\right)$} & $26^{\circ} \mathrm{C}$ & $3.40( \pm 0.3)$ & $3.44( \pm 0.32)$ \\
\hline & $31^{\circ} \mathrm{C}$ & $7.86( \pm 0.98)$ & $9.34( \pm 0.78)$ \\
\hline \multirow[t]{2}{*}{ AG biomass (g FW) } & $26^{\circ} \mathrm{C}$ & $0.19( \pm 0.02)$ & $0.18( \pm 0.02)$ \\
\hline & $31^{\circ} \mathrm{C}$ & $0.28( \pm 0.03)$ & $0.31( \pm 0.02)$ \\
\hline \multirow[t]{2}{*}{ Seed diameter (cm) } & $26^{\circ} \mathrm{C}$ & $1.03( \pm 0.03)$ & $1.05( \pm 0.04)$ \\
\hline & $31^{\circ} \mathrm{C}$ & $1.13( \pm 0.07)$ & $1.17( \pm 0.07)$ \\
\hline \multirow[t]{2}{*}{ Seed height (cm) } & $26^{\circ} \mathrm{C}$ & $1.14( \pm 0.03)$ & $1.11( \pm 0.03)$ \\
\hline & $31^{\circ} \mathrm{C}$ & $1.14( \pm 0.07)$ & $1.21( \pm 0.09)$ \\
\hline \multirow[t]{2}{*}{ Seed biomass (g FW) } & $26^{\circ} \mathrm{C}$ & $0.63( \pm 0.04)$ & $0.68( \pm 0.04)$ \\
\hline & $31^{\circ} \mathrm{C}$ & $0.73( \pm 0.05)$ & $0.76( \pm 0.07)$ \\
\hline \multirow[t]{2}{*}{$\mathrm{N}^{\circ}$ of roots } & $26^{\circ} \mathrm{C}$ & $2( \pm 0.25)$ & $1( \pm 0.06)$ \\
\hline & $31^{\circ} \mathrm{C}$ & $2( \pm 0.21)$ & $2( \pm 0.15)$ \\
\hline \multirow[t]{2}{*}{ Maximum root length $(\mathrm{cm})$} & $26^{\circ} \mathrm{C}$ & $2.92( \pm 0.42)$ & $2.43( \pm 0.21)$ \\
\hline & $31^{\circ} \mathrm{C}$ & $5.9( \pm 0.2)$ & $5.62( \pm 0.27)$ \\
\hline \multirow[t]{2}{*}{ BG biomass (g FW) } & $26^{\circ} \mathrm{C}$ & $0.12( \pm 0.02)$ & $0.05( \pm 0)$ \\
\hline & $31^{\circ} \mathrm{C}$ & $0.25( \pm 0.04)$ & $0.21( \pm 0.04)$ \\
\hline \multirow[t]{2}{*}{ Ratio AG:BG } & $26^{\circ} \mathrm{C}$ & $2.48( \pm 0.68)$ & $7.53( \pm 3.16)$ \\
\hline & $31^{\circ} \mathrm{C}$ & $1.30( \pm 0.16)$ & $2.11( \pm 0.28)$ \\
\hline \multirow[t]{2}{*}{ Ratio BG:Seed } & $26^{\circ} \mathrm{C}$ & $0.16( \pm 0)$ & $0.08( \pm 0.02)$ \\
\hline & $31^{\circ} \mathrm{C}$ & $0.33( \pm 0.05)$ & $0.27( \pm 0.04)$ \\
\hline \multirow[t]{2}{*}{ Ratio AG:Seed } & $26^{\circ} \mathrm{C}$ & $0.30( \pm 0.02)$ & $0.25( \pm 0.03)$ \\
\hline & $31^{\circ} \mathrm{C}$ & $0.40( \pm 0.02)$ & $0.43( \pm 0.03)$ \\
\hline \multirow[t]{2}{*}{ Total biomass (g FW) } & $26^{\circ} \mathrm{C}$ & $0.95( \pm 0.08)$ & $0.88( \pm 0.07)$ \\
\hline & $31^{\circ} \mathrm{C}$ & $1.23( \pm 0.13)$ & $1.28( \pm 0.13)$ \\
\hline
\end{tabular}

SA, Surface area; AG, above-ground tissues; BG, below-ground tissues.

Maximum root length and root biomass were significantly higher in the high temperature treatments (Table 4). Overall, the total seedling biomass was the highest in the high temperature treatments (Figure 2), and there was an effect of the initial seed size (Table 4). Seed biomass was the highest, with no differences among treatments, followed by AG, and lowest in BG biomass, which showed a significant decrease in lowtemperature treatments (Table 4). Seed size also had an effect on almost all biomass traits, BG:seed ratio and number of leaves (Table 4). The AG:BG biomass was the only morphological trait that significantly varied both with temperature and nutrients, with the highest ratio observed in the low temperature and high nutrient treatment, and the lowest ratio with high temperature and low nutrient treatment (Tables 2, 4). Also, significant differences were found in the ratio between AG:seed biomass and BG:seed biomass with highest ratios under the high temperature treatments. This trait was also the only morphological measurement that showed an interaction between temperature and nutrient treatments.
TABLE 3 | Biochemical and physiological traits (mean $\pm \mathrm{SE}, n=6$ ) of Enhalus acoroides seedlings in the four different temperature (Temp) and nutrient treatments at the end of the experiment.

\begin{tabular}{|c|c|c|c|}
\hline \multirow[t]{2}{*}{ Traits } & \multicolumn{3}{|c|}{ Treatments } \\
\hline & Temp & Low nutrient & High nutrient \\
\hline \multirow[t]{2}{*}{ Leaf elongation rate $\left(\mathrm{cm} \mathrm{d}^{-1}\right)$} & $26^{\circ} \mathrm{C}$ & $0.01( \pm 0.002)$ & $0.02( \pm 0.001)$ \\
\hline & $31^{\circ} \mathrm{C}$ & $0.03( \pm 0.003)$ & $0.03( \pm 0.003)$ \\
\hline \multirow[t]{2}{*}{ SA growth rate $\left(\mathrm{cm}^{2} \mathrm{~d}^{-1}\right)$} & $26^{\circ} \mathrm{C}$ & $0.11( \pm 0.01)$ & $0.11( \pm 0.01)$ \\
\hline & $31^{\circ} \mathrm{C}$ & $0.26( \pm 0.03)$ & $0.31( \pm 0.03)$ \\
\hline \multirow[t]{2}{*}{ Maximum quantum yield } & $26^{\circ} \mathrm{C}$ & $0.73( \pm 0.01)$ & $0.70( \pm 0.03)$ \\
\hline & $31^{\circ} \mathrm{C}$ & $0.75( \pm 0.01)$ & $0.67( \pm 0.05)$ \\
\hline \multirow[t]{2}{*}{ rETRmax } & $26^{\circ} \mathrm{C}$ & $16.11( \pm 2.28)$ & $15.43( \pm 2.28)$ \\
\hline & $31^{\circ} \mathrm{C}$ & $14.54( \pm 0.77)$ & $15.10( \pm 2.38)$ \\
\hline \multirow[t]{2}{*}{ Alpha } & $26^{\circ} \mathrm{C}$ & $0.70( \pm 0.01)$ & $0.66( \pm 0.03)$ \\
\hline & $31^{\circ} \mathrm{C}$ & $0.72( \pm 0.01)$ & $0.66( \pm 0.04)$ \\
\hline \multirow[t]{2}{*}{ Ek } & $26^{\circ} \mathrm{C}$ & $8.83( \pm 1.91)$ & $8.54( \pm 3.06)$ \\
\hline & $31^{\circ} \mathrm{C}$ & $8.41( \pm 1.23)$ & $8.89( \pm 1.13)$ \\
\hline \multirow[t]{2}{*}{ Leaf C (\%DW) } & $26^{\circ} \mathrm{C}$ & $31.84( \pm 0.37)$ & $30.96( \pm 0.32)$ \\
\hline & $31^{\circ} \mathrm{C}$ & $30.90( \pm 0.53)$ & $30.62( \pm 0.32)$ \\
\hline \multirow[t]{2}{*}{ Seed C (\%DW) } & $26^{\circ} \mathrm{C}$ & $35.00( \pm 0.21)$ & $33.98( \pm 0.68)$ \\
\hline & $31^{\circ} \mathrm{C}$ & $33.11( \pm 1.16)$ & $33.65( \pm 0.36)$ \\
\hline \multirow[t]{2}{*}{ Root C (\%DW) } & $26^{\circ} \mathrm{C}$ & $23.12( \pm 1.74)$ & $27.26( \pm 0.56)$ \\
\hline & $31^{\circ} \mathrm{C}$ & $24.4( \pm 2.23)$ & $23.62( \pm 2.81)$ \\
\hline \multirow[t]{2}{*}{ Leaf N (\%DW) } & $26^{\circ} \mathrm{C}$ & $2.29( \pm 0.02)$ & $2.2( \pm 0.04)$ \\
\hline & $31^{\circ} \mathrm{C}$ & $2.26( \pm 0.05)$ & $2.26( \pm 0.07)$ \\
\hline \multirow[t]{2}{*}{ Seed N (\%DW) } & $26^{\circ} \mathrm{C}$ & $1.32( \pm 0.11)$ & $1.28( \pm 0.06)$ \\
\hline & $31^{\circ} \mathrm{C}$ & $1.03( \pm 0.07)$ & $1.15( \pm 0.07)$ \\
\hline \multirow[t]{2}{*}{ Root N (\%DW) } & $26^{\circ} \mathrm{C}$ & $1.84( \pm 0.17)$ & $2.08( \pm 0.2)$ \\
\hline & $31^{\circ} \mathrm{C}$ & $1.38( \pm 0.15)$ & $1.16( \pm 0.12)$ \\
\hline \multirow[t]{2}{*}{ Leaf $\mathrm{C}: \mathrm{N}$ ratio } & $26^{\circ} \mathrm{C}$ & $13.9( \pm 0.18)$ & $14.1( \pm 0.21)$ \\
\hline & $31^{\circ} \mathrm{C}$ & $13.71( \pm 0.15)$ & $13.59( \pm 0.34)$ \\
\hline \multirow[t]{2}{*}{ Seed C:N ratio } & $26^{\circ} \mathrm{C}$ & $27.35( \pm 2.14)$ & $26.67( \pm 1.22)$ \\
\hline & $31^{\circ} \mathrm{C}$ & $32.73( \pm 1.88)$ & $29.79( \pm 2.02)$ \\
\hline \multirow[t]{2}{*}{ Root C:N ratio } & $26^{\circ} \mathrm{C}$ & $12.69( \pm 0.59)$ & $13.55( \pm 1.14)$ \\
\hline & $31^{\circ} \mathrm{C}$ & $17.90( \pm 0.67)$ & $20.24( \pm 1.46)$ \\
\hline \multirow[t]{2}{*}{ Leaf sucrose (sucrose eq $\mathrm{g}^{-1} \mathrm{DW}$ ) } & $26^{\circ} \mathrm{C}$ & $35.85( \pm 4.41)$ & $45.39( \pm 2.84)$ \\
\hline & $31^{\circ} \mathrm{C}$ & $49.13( \pm 2.77)$ & $48.30( \pm 2.50)$ \\
\hline \multirow[t]{2}{*}{ Seed sucrose (sucrose eq $\mathrm{g}^{-1} \mathrm{DW}$ ) } & $26^{\circ} \mathrm{C}$ & $88.42( \pm 10.60)$ & $69.09( \pm 14.40)$ \\
\hline & $31^{\circ} \mathrm{C}$ & $33.46( \pm 5.47)$ & $43.22( \pm 3.62)$ \\
\hline \multirow[t]{2}{*}{ Leaf starch (sucrose eq $\mathrm{g}^{-1} \mathrm{DW}$ ) } & $26^{\circ} \mathrm{C}$ & $7.23( \pm 1.63)$ & $7.83( \pm 0.78)$ \\
\hline & $31^{\circ} \mathrm{C}$ & $11.93( \pm 1.91)$ & $12.66( \pm 1.45)$ \\
\hline \multirow[t]{2}{*}{ Seed starch (sucrose eq g ${ }^{-1} \mathrm{DW}$ ) } & $26^{\circ} \mathrm{C}$ & $11.56( \pm 1.03)$ & $15.95( \pm 2.70)$ \\
\hline & $31^{\circ} \mathrm{C}$ & $13.06( \pm 1.27)$ & $9.63( \pm 1.23)$ \\
\hline
\end{tabular}

\section{Seedling Physiological and Biochemical Traits}

Leaf elongation rate was significantly higher in the high nutrient low temperature treatment $\left(0.02 \mathrm{~cm} \mathrm{~d}^{-1}\right.$, Tables 3,5$)$. With the exception of biomass traits, we found that initial seed size did not matter in seedling physiological responses, growth and photosynthetic parameters.

Photosynthetic parameters used to measure the relative photosynthetic performance of the seedlings showed little differences across treatments (Figure 3, Tables 3, 5). No photoinhibition was observed under any of the treatments as 
TABLE 4 | Results of the permutational analysis of variance (PERMANOVA) of the effects of temperature and nutrient treatments on the morphological traits of Enhalus acoroides seedlings included in Table 2, with the exception of number of roots.

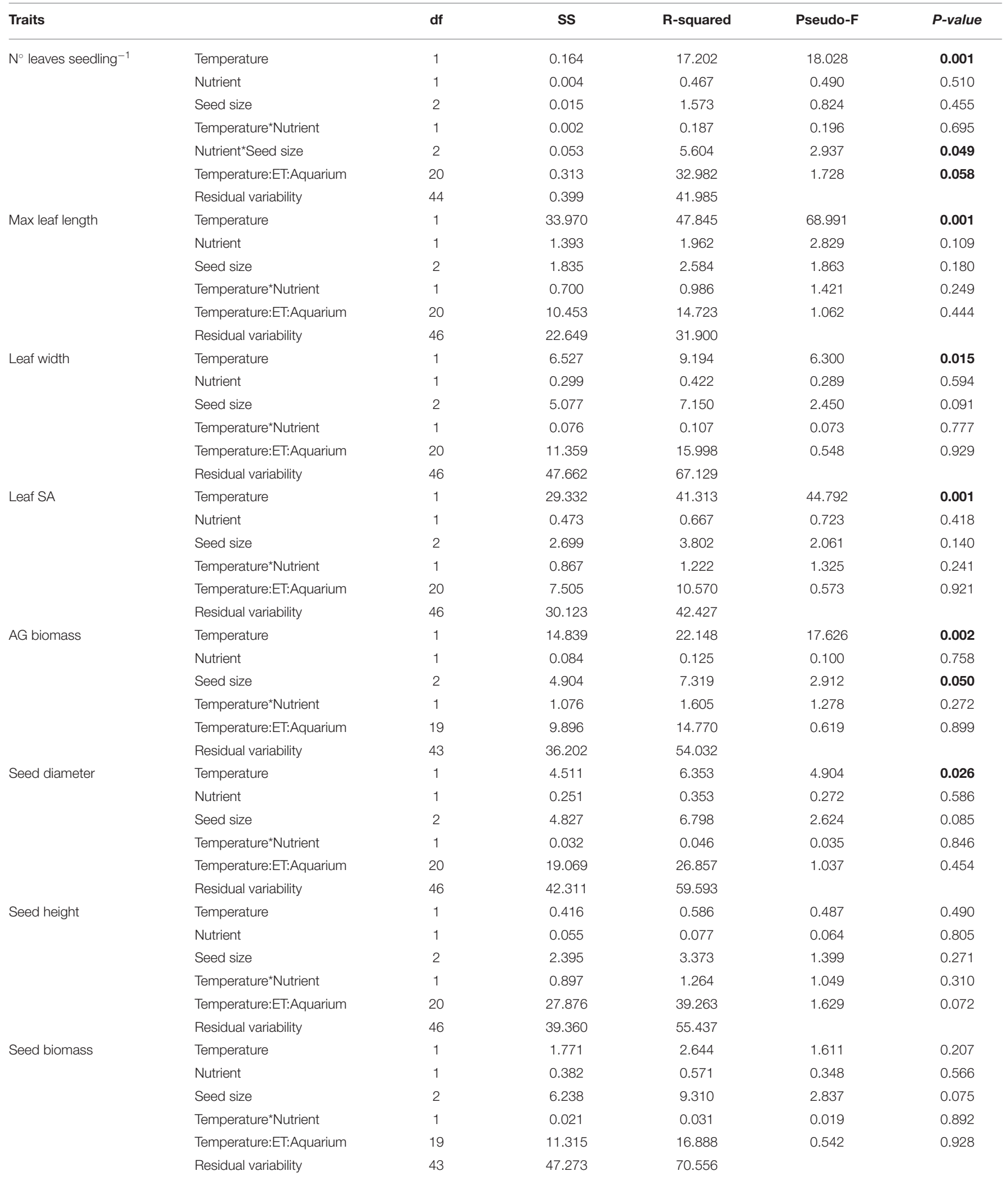


TABLE 4 | Continued

\begin{tabular}{|c|c|c|c|c|c|c|}
\hline Traits & & df & SS & R-squared & Pseudo-F & P-value \\
\hline \multirow[t]{6}{*}{ Max root length } & Temperature & 1 & 29.864 & 42.663 & 45.703 & 0.001 \\
\hline & Nutrient & 1 & 0.111 & 0.159 & 0.171 & 0.672 \\
\hline & Seed size & 2 & 3.155 & 4.508 & 2.414 & 0.115 \\
\hline & Temperature^Nutrient & 1 & 0.356 & 0.508 & 0.544 & 0.458 \\
\hline & Temperature:ET:Aquarium & 20 & 7.110 & 10.157 & 0.544 & 0.926 \\
\hline & Residual variability & 45 & 29.404 & 42.006 & & \\
\hline \multirow[t]{6}{*}{ BG biomass } & Temperature & 1 & 18.659 & 26.280 & 27.083 & 0.001 \\
\hline & Nutrient & 1 & 0.678 & 0.955 & 0.984 & 0.349 \\
\hline & Seed size & 2 & 7.049 & 3.929 & 5.116 & 0.011 \\
\hline & Temperature^Nutrient & 1 & 0.606 & 0.854 & 0.880 & 0.373 \\
\hline & Temperature:ET:Aquarium & 20 & 12.316 & 17.347 & 0.894 & 0.590 \\
\hline & Residual variability & 46 & 31.692 & 44.636 & & \\
\hline \multirow[t]{6}{*}{ Ratio AG:BG } & Temperature & 1 & 7.837 & 13.750 & 10.418 & 0.003 \\
\hline & Nutrient & 1 & 4.448 & 7.804 & 5.912 & 0.018 \\
\hline & Seed size & 2 & 0.789 & 1.383 & 0.524 & 0.628 \\
\hline & Temperature^Nutrient & 1 & 0.203 & 0.356 & 0.270 & 0.605 \\
\hline & Temperature:ET:Aquarium & 19 & 18.897 & 33.152 & 1.322 & 0.233 \\
\hline & Residual variability & 33 & 24.826 & 43.555 & & \\
\hline \multirow[t]{6}{*}{ Ratio BG:Seed } & Temperature & 1 & 20.217 & 30.174 & 31.709 & 0.001 \\
\hline & Nutrient & 1 & 0.861 & 1.286 & 1.351 & 0.246 \\
\hline & Seed size & 2 & 7.188 & 10.728 & 5.637 & 0.008 \\
\hline & Temperature*Nutrient & 1 & 1.277 & 1.906 & 2.003 & 0.147 \\
\hline & Temperature:ET:Aquarium & 19 & 10.041 & 14.987 & 0.829 & 0.665 \\
\hline & Residual variability & 43 & 27.416 & 40.919 & & \\
\hline \multirow[t]{6}{*}{ AG:Seed ratio } & Temperature & 1 & 20.678 & 30.863 & 31.457 & 0.001 \\
\hline & Nutrient & 1 & 0.107 & 0.160 & 0.163 & 0.678 \\
\hline & Seed size & 2 & 0.926 & 1.382 & 0.704 & 0.502 \\
\hline & Temperature*Nutrient & 1 & 2.973 & 4.437 & 4.523 & 0.032 \\
\hline & Temperature:ET:Aquarium & 19 & 14.049 & 20.969 & 1.125 & 0.370 \\
\hline & Residual variability & 43 & 28.266 & 42.188 & & \\
\hline \multirow[t]{7}{*}{ Total biomass } & Temperature & 1 & 8.619 & 12.864 & 10.194 & 0.003 \\
\hline & Nutrient & 1 & 0.085 & 0.127 & 0.100 & 0.752 \\
\hline & Seed size & 2 & 8.243 & 12.303 & 4.875 & 0.014 \\
\hline & Temperature^Nutrient & 1 & 0.110 & 0.164 & 0.130 & 0.711 \\
\hline & Nutrient ${ }^{\star}$ Seed size & 2 & 6.267 & 9.353 & 3.706 & 0.040 \\
\hline & Temperature:ET:Aquarium & 19 & 9.011 & 13.449 & 0.561 & 0.905 \\
\hline & Residual variability & 41 & 34.666 & 51.740 & & \\
\hline
\end{tabular}

P-values are in bold when significant differences were observed ( $\leq 0.05)$ SA, Surface area; AG, above-ground tissues; BG, below-ground tissues.

shown by the RLCs (Figure 3). From the curve fit parameters, only maximum quantum yield values were significantly higher under high temperature treatments (Table 5).

The photosynthetic performance of the seedlings was affected by the nested blocking variables, as reflected by the significant effect they have on rETRmax, alpha and Ek. Due to the high variability between enclosures, any effect of the temperature and nutrient treatments may have been confounded, and therefore we cannot draw any conclusion about the influence of these factors on Enhalus seedlings.

Values of $\% \mathrm{C}$ did not show any significant difference within any of the seedlings parts, leaves, seeds or roots (Tables 3, 5). In contrast, $\% \mathrm{~N}$ of the seeds and roots was significantly lower in the high-temperature treatments, but did not change in leaves. Therefore, C:N ratio of leaves showed no significant differences, while $\mathrm{C}: \mathrm{N}$ ratio in seeds and roots were the highest under the high temperature and low nutrient treatment (Table 3).

Concentrations of NSC in the leaves were significantly higher in high temperature treatments (Table 5). Although both types of NSC, sucrose and starch, showed significant differences in the leaves among treatments $(P<0.05)$, concentrations of sucrose in the seeds showed the opposite trends. The lowest concentrations of sucrose in seeds were observed in the high temperature treatments, while starch concentration in the seeds was the lowest in the high temperature and high nutrient treatment and the highest in the low temperature and high nutrient treatment. 


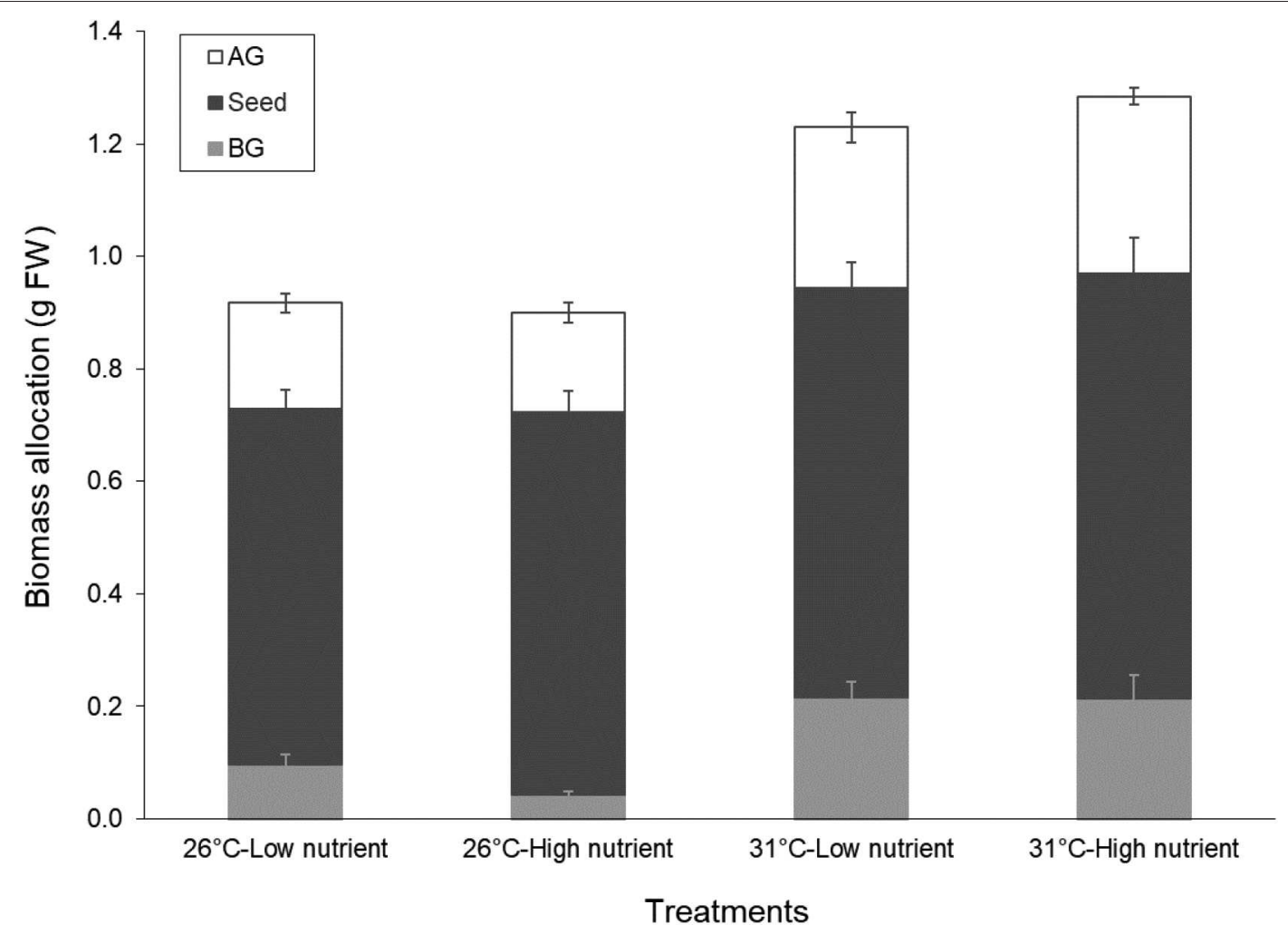

FIGURE 2 | Allocation of above-ground (blades, AG), seed, and below-ground (roots, BG) biomass in the seedlings of Enhalus acoroides in the four different temperature and nutrient treatments at the end of the experiment. Values are mean $\pm \operatorname{SE}(n=6)$. Statistical results are shown in Table 4.

\section{DISCUSSION}

Overall, we found that E. acoroides seedlings were highly tolerant to an extended exposure to high temperature within the reported tolerance limits for adult individuals of this species with enhanced development of new tissue. There were no signs of seedling mortality nor stress response during the experiment under any of the treatments. This indicated that the initial development of the seedling from a seed of this species showed resilience under future average temperature increases expected to occur under climate change impacts. Additionally, increased temperature stimulated rapid development and growth of both AG and BG tissues compared to ambient temperature. In contrast, nutrient enrichment did not increase growth performance of $E$. acoroides seedlings, suggesting that they rely on internal nutrient and energy stores during this stage. Multiple stressor experiments are now highlighted as the necessary steps for predicting the consequences under future scenarios, as interactions between stressors could be synergistic, additive or antagonistic (Gunderson et al., 2016). In our experiment, however, the effects on most traits showed no strong interactions, indicating a lack of synergistic or antagonistic effects under combined stressors. The combined treatments, therefore, can be considered additive, in which nutrient effects were generally lacking and did not add further to the temperature effect.

\section{Seedling Responses to Increased Temperature}

The increase in size and quantity of the majority of morphological and physiological traits of the leaves and roots under increasing temperature indicates that this abiotic factor may be an important driver of seedling development of tropical species at the seedling phase. This is in contrast to previous studies on subtropical and temperate seagrass species that showed negative effects on seedling performance under increasing temperatures (Abe et al., 2009; Niu et al., 2012; Guerrero-Meseguer et al., 2017; Pereda-Briones et al., 2019). The seedlings of Zostera japonica, for example, survived up to $29^{\circ} \mathrm{C}$, but died at temperatures above $30^{\circ} \mathrm{C}$ in a temperature tolerance study (Abe et al., 2009). In Zostera marina seedlings, growth was inhibited at temperatures higher than $30^{\circ} \mathrm{C}$, and photochemical pigments were negatively affected at $25^{\circ} \mathrm{C}$, a temperature that is 8 to $9^{\circ} \mathrm{C}$ higher than the optimum temperature for this species (Niu et al., 2012). The opposite effect of rising temperatures between our study and other studies could be due to different reasons, such as the inter-species differences to responses to temperature changes. Unlike Z. marina, which is a temperate species, $E$. acoroides is tropical, with a higher temperature range in its native distribution. Meanwhile, positive effects of temperature have also been observed during germination processes in some subtropical seagrass species, such as Ruppia sinensis collected from northern China (Gu et al., 2018). Such effects could also be positive in 
TABLE 5 | Results of the permutational analysis of variance (PERMANOVA) of the effects of temperature and nutrient treatments on the biochemical and physiological traits of Enhalus acoroides seedlings included in Table 3, with the exception of starch concentration in seeds.

\begin{tabular}{|c|c|c|c|c|c|c|}
\hline Traits & & df & ss & R-squared & Pseudo-F & $P$-value \\
\hline \multirow[t]{4}{*}{ Leaf elongation rate } & Temperature & 1 & 27.285 & 38.429 & 51.351 & 0.001 \\
\hline & Nutrient & 1 & 2.942 & 4.144 & 5.537 & 0.024 \\
\hline & Temperature*Nutrient & 1 & 0.827 & 1.164 & 1.556 & 0.214 \\
\hline & Temperature:ET:Aquarium & 19 & 14.594 & 20.555 & 1.373 & 0.178 \\
\hline \multirow{5}{*}{ SA growth rate } & Nutrient & 1 & 1.608 & 2.331 & 1.880 & 0.205 \\
\hline & Seed size & 2 & 0.749 & 1.085 & 0.438 & 0.647 \\
\hline & Temperature*Nutrient & 1 & 0.170 & 0.246 & 0.199 & 0.681 \\
\hline & Temperature:ET:Aquarium & 20 & 13.205 & 19.137 & 0.772 & 0.734 \\
\hline & Residual variability & 44 & 37.636 & 54.545 & & \\
\hline \multirow{2}{*}{ Max quantum yield } & Temperature:ET:Aquarium & 17 & 26.673 & 44.455 & 2.427 & 0.018 \\
\hline & Residual variability & 38 & 24.569 & 40.948 & & \\
\hline \multirow[t]{6}{*}{ rETRmax } & Temperature & 1 & 0.001 & 0.002 & 0.001 & 0.969 \\
\hline & Nutrient & 1 & 0.000 & 0.000 & 0.000 & 0.989 \\
\hline & Seed size & 2 & 1.377 & 2.295 & 0.639 & 0.546 \\
\hline & Temperature*Nutrient & 1 & 1.491 & 2.486 & 1.384 & 0.255 \\
\hline & Temperature:ET:Aquarium & 17 & 16.188 & 26.981 & 0.884 & 0.589 \\
\hline & Residual variability & 38 & 40.941 & 68.236 & & \\
\hline \multirow[t]{2}{*}{ Alpha } & Temperature & 1 & 1.739 & 2.898 & 2.605 & 0.136 \\
\hline & Nutrient & 1 & 1.071 & 1.786 & 1.605 & 0.210 \\
\hline \multirow{2}{*}{ Ek } & Temperature:ET:Aquarium & 17 & 28.129 & 46.882 & 2.122 & 0.035 \\
\hline & Residual variability & 38 & 29.626 & 49.376 & & \\
\hline \multirow[t]{5}{*}{ Leaf C } & Temperature & 1 & 2.7266 & 11.855 & 3.971 & 0.059 \\
\hline & Nutrient & 1 & 2.2771 & 9.9 & 3.316 & 0.078 \\
\hline & Temperature*Nutrient & 1 & 0.6059 & 2.634 & 0.882 & 0.351 \\
\hline & Temperature:ET & 2 & 5.0314 & 21.876 & 3.664 & 0.050 \\
\hline & Residual variability & 18 & 12.3591 & 53.735 & & \\
\hline \multirow[t]{5}{*}{ Seed C } & Temperature & 1 & 1.8067 & 8.212 & 2.592 & 0.121 \\
\hline & Nutrient & 1 & 1.6922 & 7.692 & 2.427 & 0.132 \\
\hline & Temperature*Nutrient & 1 & 0.4675 & 2.125 & 0.671 & 0.425 \\
\hline & Temperature:ET & 2 & 6.1823 & 28.101 & 4.434 & 0.039 \\
\hline & Residual variability & 16 & 11.8513 & 53.869 & & \\
\hline \multirow[t]{5}{*}{ Root C } & Temperature & 1 & 0.2007 & 1.004 & 0.228 & 0.663 \\
\hline & Nutrient & 1 & 2.8388 & 14.194 & 3.217 & 0.080 \\
\hline & Temperature*Nutrient & 2 & 3.7103 & 18.552 & 4.205 & 0.058 \\
\hline & Temperature:ET & 2 & 0.0153 & 0.077 & 0.009 & 0.995 \\
\hline & Residual variability & 15 & 13.2349 & 66.174 & & \\
\hline
\end{tabular}


TABLE 5 | Continued

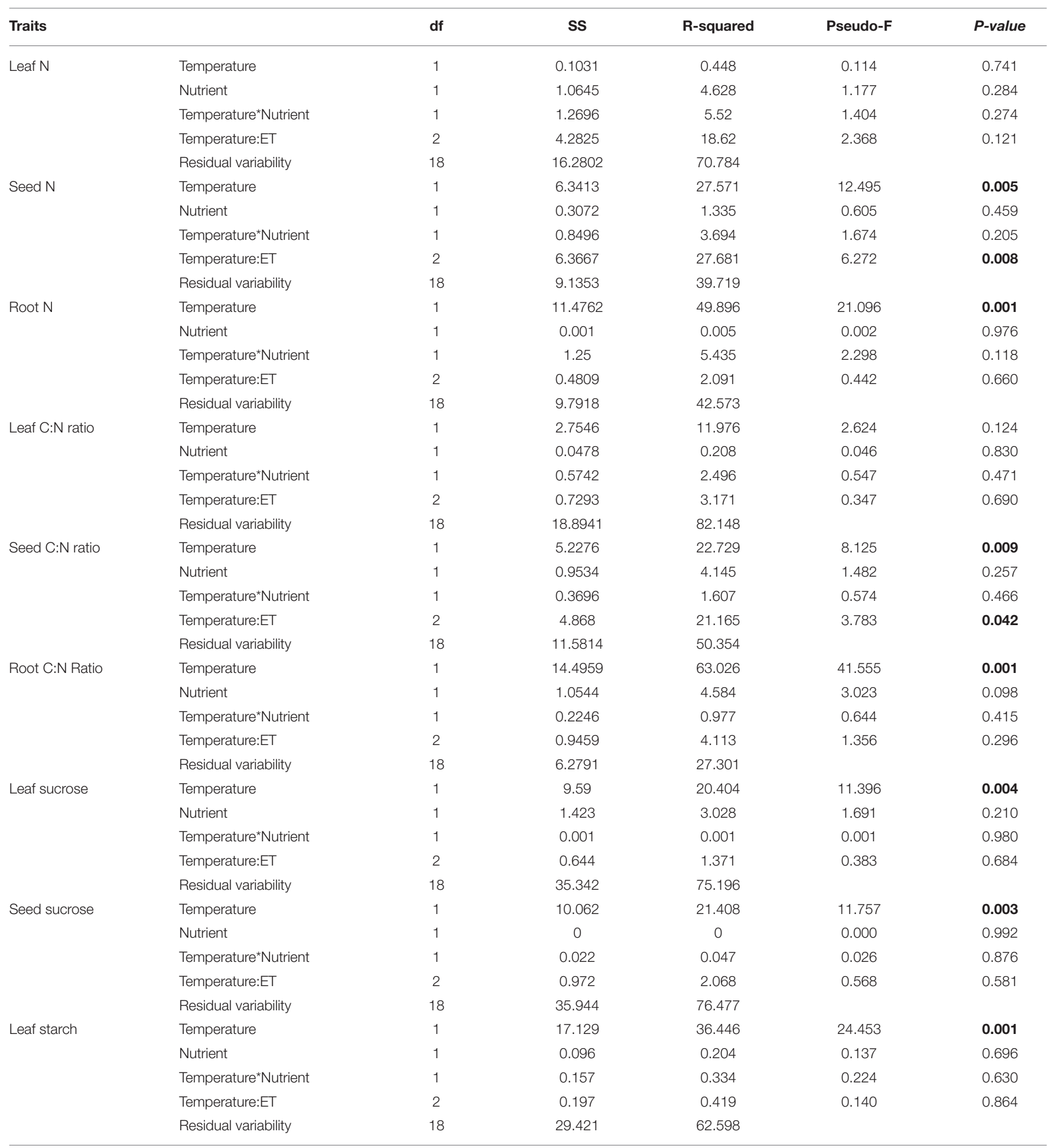

$P$-values are in bold when significant differences were observed $(\leq 0.05)$.

recently germinated seeds, such as the ones used in our study. On the other hand, selected target temperatures of the different experimental studies could draw different conclusions. As long as the temperature is not increased above the thermal tolerance of the species in question, higher physiological performance in terms of growth and photosynthesis are more probable. It is possible that seedlings in this study were still within their thermal niche, as adult E. acoroides plants grow naturally in 
seawater within a temperature range of 24 to $33^{\circ} \mathrm{C}$ (Agawin et al., 2001). More specifically, average seawater temperature at mid-day recorded in Barrang Lompo, Spermonde Archipelago (E. acoroides fruit collecting site) during December to January was $29.3 \pm 0.3^{\circ} \mathrm{C}$ (Artika et al., 2019), and $31.5 \pm 0.1^{\circ} \mathrm{C}$ during April to May (Ambo-Rappe, 2014). Our study did not intend to find the optimal temperature for growth of E. acoroides seedlings, but rather to test the effect of increasing temperature under different nutrient regimes. Further research is required to determine the thermal niche and optimum thermal regime for these seedlings, as well as temperatures in which thermal stress is observed.

The combined enhancement of the various morphological leaf trait responses, including the increase in number of leaves, maximum leaf length, leaf SA and AG biomass, confirmed the positive growth response of AG tissue of the seedlings observed under increasing temperature, specifically the higher leaf elongation rates under high temperature. Root trait responses including the increase in number of roots per seedling, maximum root length, and BG biomass, additionally supported the positive growth response of $\mathrm{BG}$ tissue to increasing temperature. In combination, we suggest that these morphological traits can be used as indicators of either healthy or suboptimal E. acoroides seedling development under climate related effects. Overall, the strategy of seedlings also showed that under lower temperature (which is suboptimal for the tropical species), more energy goes for development of AG biomass first and less biomass allocation to BG tissues (see Figure 2). This was contrary to biomass accumulation under high temperature treatments, where AG and BG tissues were equally supported, suggesting that temperature plays a role in determining energy resource allocation in tropical seagrass seedling development. This finding is interesting in the context of climate change, specifically with respect to possible pole-wards migration. Many tropical species ranges are moving to higher latitudes as average water temperatures rise. These include animals and plants (Doney et al., 2011), and E. acoroides could be expected to migrate in a similar manner to mangroves (Osland et al., 2016). However, this energy budget allocation pattern might be a limiting factor because root development is key when establishing and maintaining a seagrass meadow. Less BG development under temperatures at the lower range of tolerance (even seasonally) could make otherwise suitable habitat difficult to colonize, especially as hydrodynamic forces (e.g., wave action) tend to increase in the subtropics and temperate regions compared to the tropical/equatorial region. The slow root development under high nutrient levels could further impede seedling establishment in cooler waters with natural or manmade eutrophic conditions.

Additionally, seed size of the seedlings matters for morphological responses; this has been widely observed in terrestrial plants (e.g., Kennedy et al., 2004) and just in Posidonia australis seagrass seedlings (Glasby et al., 2014). This could be related with the positive relation found between starch and nutrient contents and seedling size (Delefosse et al., 2016). In our study, the decrease in $\% \mathrm{~N}$ and sucrose content of the seed also indicates that growth and biomass allocation was supported by internal nutrient and energy stores found in the seed. This has been previously observed in temperate seagrass seedlings under different stressors, such as $\mathrm{CO}_{2}$ enrichment, invasive algae or temperature (Hernán et al., 2016; Guerrero-Meseguer et al., 2017; Pereda-Briones et al., 2019).

\section{Seedling Response to Increased Nutrients}

Our results show that nutrient affected the AG:BG ratio and leaf elongation rate of $E$. acoroides seedlings only at the low temperature treatment. This suggests that the initial development of the seedling phase of $E$. acoroides does not depend much on the availability of external nutrients, at least on these newly germinated seedlings.

While it seems that seedlings of some opportunistic species, namely C. nodosa or Amphibolis antarctica, take nutrients from the water (Paling and McComb, 1994; Alexandre et al., 2018), other studies show that seagrass seedlings in some other species, including Posidonia oceanica, use internal resources on the early stages of development (Balestri et al., 2009). Moreover, despite this capacity for nutrient uptake, the responses in terms of growth and enhanced morphological features are variable, even within the same species (Zarranz et al., 2010; Pereda-Briones et al., 2018). Different factors including environment, availability of phosphate and its balance with nitrogen, seedling's age, or the seed size have been discussed as the reason for the variability of responses (Balestri et al., 2009; Delefosse et al., 2016; Alexandre et al., 2018).

This last feature, seed size, is related with the absolute quantity of nutrients in the seeds (Delefosse et al., 2016). In this way, E. acoroides seedlings have common features with other persistent species such as Posidonia sp., as seeds are bigger in size compared to other fast-growing species (Orth et al., 2007). Therefore, the ability of $E$. acoroides to produce big nutrient-rich seeds, as also observed in other persistent species like $P$. oceanica, may be a strategy to allow prolonged seedling development in oligotrophic environments (Balestri et al., 2009). In this way, studies with persistent seagrasses showed that seedling growth was more dependent on seed nutrient reserves rather than the external nutrient additions (Statton et al., 2014).

In this study, the eutrophic conditions in the high nutrient treatment aquaria are confirmed by the enhanced microalgae growth and the significant effect on some adult seagrass biochemical traits, including higher leaf nitrogen, free amino acid content or enhanced leaf SA (Viana et al., in prep). These adult seagrasses, namely Thalassia hemprichii and Cymodocea serrulata, have greater SA and potentially higher absolute uptake rates than seedlings, therefore differences between them could be expected. Moreover, the former rely mainly on external nutrient concentrations for growth (Viana et al., 2019), contrary to recently germinated seedlings which can use resources stored in the seed (Balestri et al., 2009). Competition for nutrients among microalgae, seagrass adults and seedlings, however, cannot be discarded, but was not directly measured in this study. Nevertheless, enhanced leaf elongation and AG:BG ratio, plus evidence of former studies for persistent seagrasses and the seed features of $E$. acoroides suggest that it is very likely that the seedlings in this study rely primarily on nutrient reserves in the seeds. 


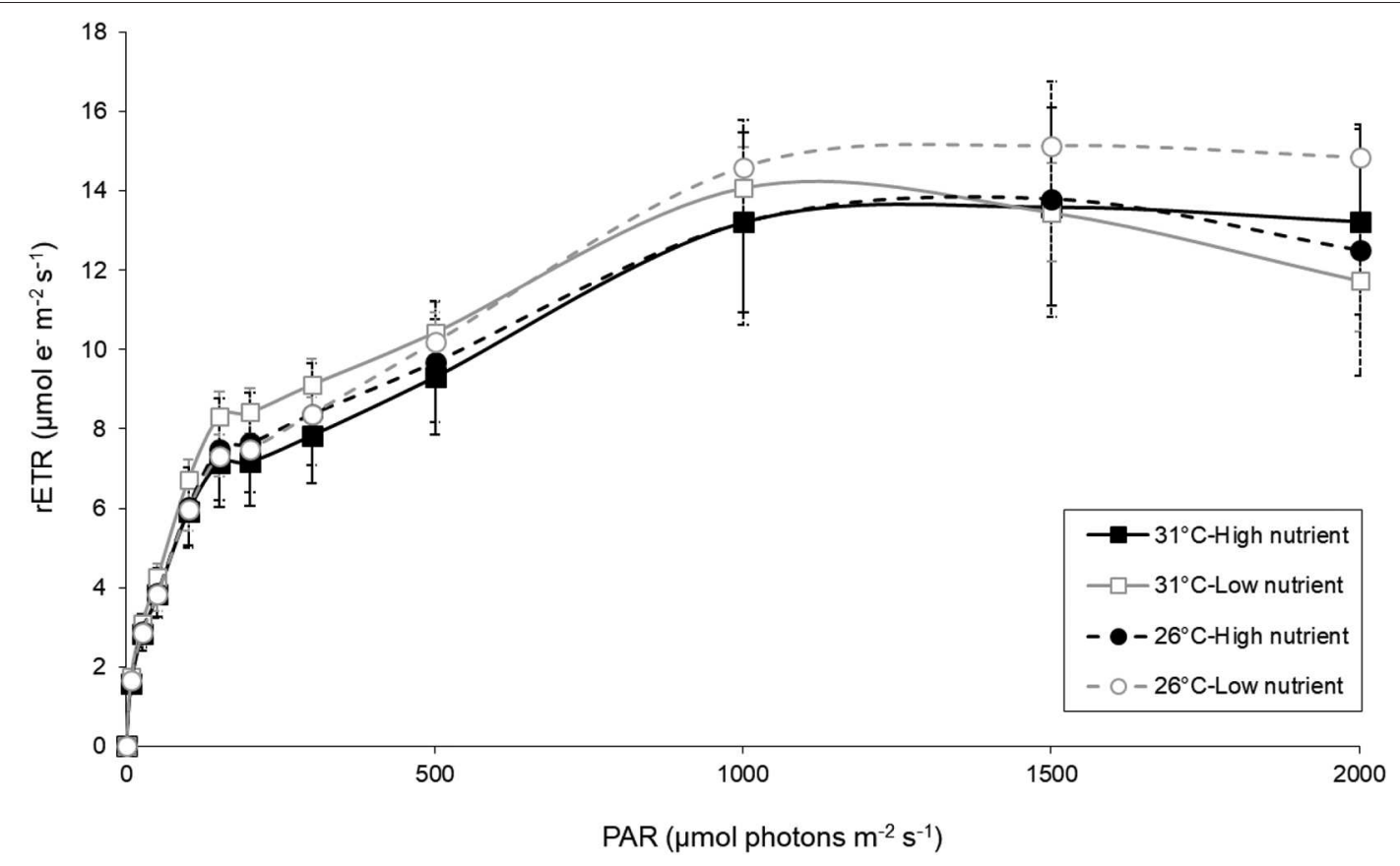

FIGURE 3 | Rapid light curves. Relative electron transport rate (rETR) as a function of photosynthetic active radiation (PAR) on leaves of Enhalus acoroides seedlings in the four different temperature and nutrient treatments at the end of the experiment. Values are mean \pm SE $(n=5-6)$.

The findings of this study are the first data available on Enhalus seedling response to nutrients, and, as far as we know, is the first study among tropical seagrass seedlings. With the exception of a few studies on seedlings from temperate seagrasses in which no positive effects on physiology, growth, survival or photosynthetic potential were observed with nutrients (Glasby et al., 2014; Alexandre et al., 2018), most studies on nutrientenrichment effects have been done on adult stages of seagrasses with mixed results. For example, while nutrient enrichment often has an effect on seagrass tissue nutrient content (e.g., Ontoria et al., 2019; Viana et al., in prep), it does not always have a significant effect on leaf length, leaf width and seagrass production, as has been shown in Thalassia testudinum (Heck et al., 2000). Z. marina, on the other hand, has been found to survive and stay healthy under high nutrient enrichment for 2 weeks, as under natural conditions this species is acclimated and often exposed to high nutrient concentrations (Kaldy, 2014). Other studies that have reviewed seagrass responses to nutrients show that a number of environmental factors, such as sedimentary characteristics or water velocity, and intraspecific characteristics, such as seagrass leaf SA, influence nutrient limitation in seagrasses (Short, 1987; Lee et al., 2007).

Our results are in line with previous studies which did not observe interactive effects of both factors on adult temperate seagrass plants (Touchette and Burkholder, 2002; Kaldy, 2014; Moreno-Marín et al., 2018; Mvungi and Pillay, 2019; Ontoria et al., 2019) and tropical seagrass plants (Viana et al., in prep). In these studies, the combination of effects of nutrient enrichment of the water column and increasing temperature did not show clear effects on seagrass plants. In contrast, other previous studies showed that morphological traits, such as leaf length, growth or number of leaves per shoot, were the most variable traits under the influence of both factors (Bintz et al., 2003; Mvungi and Pillay, 2019). Interactive effects on the response in the $\% \mathrm{~N}$ of the leaves were only observed in $Z$. marina (Moreno-Marín et al., 2018). Otherwise, interactive effects were observed when temperature was combined with other nutrient sources such as labile organic $\mathrm{C}$ in the sediment in C. nodosa (Ontoria et al., 2019). Therefore, there is still a limited interaction between temperature and nutrient enrichment.

Although nutrient effects may be considered as positive on seagrass individual traits, many studies of nutrient enrichment on seagrasses address the negative indirect effects of eutrophication. This is supported by the fact that enrichment of nutrients can cause algae blooms which will reduce light and contribute to the decline of seagrass (McGlathery, 2001). In our experiment, nutrient treatments led to higher chlorophyll concentrations in the water. However, no significant negative effects of the eutrophication in our tanks were found on seedling morphology and physiology, indicating that light was not limiting seedling growth. This is furthermore supported by the lack of an effect on the photosynthetic performance across treatments, as shown by the fluorescence data (see Table 3). This implies that initial seedling development is not light or nutrient limited. Actually, while rETRmax values for adult E. acoroides individuals fall within 45-200 $\mu \mathrm{mol} \mathrm{e} \mathrm{e}^{-} \mathrm{m}^{-2} \mathrm{~s}^{-1}$ (Jiang et al., 2014; MoreiraSaporiti et al., in prep) values in our study are 3- to 8-fold lower (Figure 3). This suggests that photosynthesis in E. acoroides seedlings might develop later, as observed in experiments with C. nodosa (Alexandre et al., 2018). 


\section{Ecological Implications}

In addition to being a critical stage (Ambo-Rappe and Yasir, 2015) for further seagrass development, the seedling stage response to climate change and nutrient enrichment has been little studied compared to adult seagrasses (Touchette and Burkholder, 2002; Kaldy, 2014; Moreno-Marín et al., 2018; Mvungi and Pillay, 2019; Ontoria et al., 2019). Overall, as far as we know, even less data is available on seagrass seedling responses in tropical species. This is the first study to suggest that the seedling stage of a tropical seagrass may be tolerant to and even positively affected by an extended exposure to the current ambient maximum temperature. This implies that extended exposure to warmer temperatures such as those close to the maximum as that expected under climate change, will not affect seedling survival. To further test temperature tolerance of tropical seagrass seedlings, however, we would need to carry out experiments under a higher range of temperatures (above $32^{\circ} \mathrm{C}$ ). Additionally, we showed that increased nutrient inputs may play a less important role in seedling growth response during its initial growth phase, due to internal nutrient reserves in the seed. As nutrient enrichment has direct and indirect effects, the seedling performance under more persistent eutrophication processes, during which organic matter concentration increases in the sediment or light deprivation happens, should be addressed. We should also consider further studies on the effect of increasing temperature and nutrients on reproductive outputs of the adult plants, including number of fruits, number of seed per fruit, and the size on the fruit and the seed, as well as energy reserves of the seed. All these factors combined will influence longterm seagrass resilience to climate related and local stressors, as well as restoration programs based on seedling establishment. This experiment provides interesting results but there are still a large number of gaps and the need to continue researching how factors related to global change affects the success in seedlings of seagrass. This information would help in future management plans and recovery.

Moreover, this is the first step in studying the combined impact of temperature and nutrients on seagrass seedlings. In the natural environment, biotic and abiotic interactions with the other elements in the ecosystem might also change (Brodeur et al., 2015; Hernán et al., 2017; Pereda-Briones et al., 2019) and, therefore, need to be considered in combination with these stressors. Variations in seedling traits due to temperature and nutrients might have an influence in their functions, and therefore in a number of seagrass ecosystem services, as has been observed to happen with other stressors (Hernán et al., 2016, 2017). Additionally, climate change not only will bring higher average temperatures but also more frequent and adverse events, such as heat waves, that might affect seagrass seedlings differently than smaller increments of higher constant temperature exposure (Guerrero-Meseguer et al., 2017).

Enhanced growth under sub-lethal temperatures at the seedling phase could improve the resilience capacity of $E$. acoroides under natural heat stress processes or in restoration attempts. Higher temperatures will enhance a faster AG and BG development providing further root development. This is critical for stabilization into sediment, and the survival of the whole plant in the following life stages. This step, when the anchoring capacity of the seedling happens, is the bottleneck to seagrass further development (Ambo-Rappe and Yasir, 2015). The ability of seeds to germinate and remain attached to ever-changing sediments within the marine environment is a critical factor in the establishment of new populations and the ongoing survival of pre-existing genetically diverse populations.

Combining morphological, biochemical, physiological, and life history traits allowed us to better understand the effects of environmental stressors on ecological functioning and survival of seedlings, and the influence on future seagrass community dynamics. Further study of seedling and adult plant traits of other tropical seagrass species is important to filling gaps of knowledge of tropical seagrass ecology and future consequences of environmental change on this critical ecosystem.

\section{DATA AVAILABILITY STATEMENT}

The datasets generated for this study are available on request to the corresponding author.

\section{AUTHOR CONTRIBUTIONS}

MT and IV designed the experiment. SA, AM-S, and IV carried out the experiment and processed the samples. AM-S ran the statistical analysis. SA, MT, and RA-R wrote a first version of the manuscript. All authors made significant contributions to the manuscript and critically revised the different versions of the manuscript.

\section{FUNDING}

SA was supported by PMDSU (Pendidikan Magister Menuju Doktor untuk Sarjana Unggul) scholarship (SP DIPA042.06.1.401516/2018) from the Ministry of Research and Technology of Higher Education (Indonesia) in collaboration with Hasanuddin University. The present paper is part of the project SEAMAC [Seagrass and macroalgal community dynamics and performance under environmental change funded by the German Research Foundation (DFG; TE 1046/3-1)] awarded to MT. IV was awarded with a postdoctoral fellowship of the Leibniz-DAAD postdoctoral programme (Germany) and Xunta de Galicia (Consellería de Educación, Universidad e Formación Profesional) postdoctoral programme (ED481B-2016/189-0).

\section{ACKNOWLEDGMENTS}

We would like to thank to the Chemistry laboratory and MAREE facilities at the ZMT for the technical support during the experiment and the sample analysis. We are grateful to the two reviewers for their useful comments that have helped to improve the first version of the manuscript. 


\section{REFERENCES}

Abe, M., Yokota, K., Kurashima, A., and Maegawa, M. (2009). High water temperature tolerance in photosynthetic activity of Zostera japonica ascherson and graebner seedlings from ago bay, mie prefecture, central Japan. Fisheries Sci. 75, 1117-1123. doi: 10.1007/s12562-009-0141-x

Agawin, N. S., Duarte, C. M., Fortes, M. D., Uri, J. S., and Vermaat, J. E. (2001). Temporal changes in the abundance, leaf growth and photosynthesis of three co-occurring Philippine seagrasses. J. Exp. Mar. Biol. Ecol. 260, 217-239. doi: 10.1016/S0022-0981(01)00253-2

Alexandre, A., Silva, J., and Santos, R. (2018). Light is more important than nutrient ratios of fertilization for Cymodocea nodosa seedling development. Front. Plant Sci. 9:768. doi: 10.3389/fpls.2018.00768

Ambo-Rappe, R. (2014). Developing a methodology of bioindication of human-induced effects using seagrass morphological variation in spermonde archipelago, South Sulawesi, Indonesia. Mar. Pollut. Bull. 86, 298-303. doi: 10.1016/j.marpolbul.2014.07.002

Ambo-Rappe, R., La Nafie, Y. A., Syafiuddin., Limbong, S. R., Asriani, N., Handayani, N. T., et al. (2019). Short communication: restoration of seagrass enhalus acoroides using a combination of generative and vegetative techniques. Biodiversitas 20, 3358-3363. doi: 10.13057/biodiv/d201132

Ambo-Rappe, R., and Yasir, I. (2015). The effect of storage condition on viability of Enhalus acoroides seedlings. Aquat. Bot. 127, 57-61. doi: 10.1016/j.aquabot.2015.07.004

Anderson, M. J., Gorley, R. N., and Clarke, K. R. (2008). PERMANOVA + for PRIMER: Guide to Software and Statistical Methods. Plymouth: PRIMER-E.

Artika, S. R., Kneer, D., Ambo-Rappe, R., Syahid, S., and Teichberg, M. (2019). Decreasing $\mathrm{pH}$ affects seagrass epiphyte communities. IOP Conf. Ser. Earth Environ. Sci. 253:012024. doi: 10.1088/1755-1315/253/1/012024

Balestri, E., Gobert, S., Lepoint, G., and Lardicci, C. (2009). Seed nutrient content and nutritional status of Posidonia oceanica seedlings in the northwestern Mediterranean Sea. Mar. Ecol. Prog. Ser. 388, 99-109. doi: 10.3354/meps08104

Bewley, J. D., and Black, M. (1994). Seeds: Physiology of Development and Germination. Boston, MA: Springer.

Bintz, J. C., Nixon, S. W., Buckley, B. A., and Granger, S. L. (2003). Impacts of temperature and nutrients on coastal lagoon plant communities. Estuaries 26:765. doi: 10.1007/BF02711987

Bird, K. T., Johnson, J. R., and Jewett-Smith, J. (1998). In vitro culture of the seagrass Halophila decipiens. Aquat. Bot. 60, 377-387. doi: 10.1016/S0304-3770(97)00093-4

Brodeur, M. C., Piehler, M. F., and Fodrie, F. J. (2015). Consumers mitigate heat stress and nutrient enrichment effects on eelgrass Zostera marina communities at its southern range limit. Mar. Ecol. Prog. Ser. 525, 53-64. doi: $10.3354 /$ meps 11186

Brun, F. G., Hernández, I., Vergara, J. J., Peralta, G., and Pérez-Lloréns, J. L. (2002). Assessing the toxicity of ammonium pulses to the survival and growth of Zostera noltii. Mar. Ecol. Prog. Ser. 225, 177-187. doi: 10.3354/meps225177

Bulthuis, D. A. (1987). Effects of temperature on photosynthesis and growth of seagrasses. Aquat. Bot. 2, 27-40. doi: 10.1016/0304-3770(87)90084-2

Burkholder, J. M., Mason, K. M., and Glasgow, H. B. Jr. (1992). Water-column nitrate enrichment promotes decline of eelgrass Zostera marina: evidence from seasonal mesocosm experiments. Mar. Ecol. Prog. Ser. 81, 163-178. doi: $10.3354 /$ meps 081163

Burkholder, J. M., Tomasko, D. A., and Touchette, B. W. (2007). Seagrasses and eutrophication. J. Exp. Mar. Biol. Ecol. 350, 46-72. doi: 10.1016/j.jembe.2007.06.024

Cambridge, M. L., Chiffings, A. W., Brittan, C., Moore, L., and McComb, A. J. (1986). The loss of seagrass in cockburn sound, Western Australia. II. Possible causes of seagrass decline. Aquat. Bot. 24, 269-285. doi: 10.1016/0304-3770(86)90062-8

Campbell, J. E., Altieri, A. H., Johnston, L. N., Kuempel, C. D., Paperno, R., Paul, V. J., et al. (2018). Herbivore community determines the magnitude and mechanism of nutrient effects on subtropical and tropical seagrasses. J. Ecol. 106, 401-412. doi: 10.1111/1365-2745.12862

Campbell, S. J., McKenzie, L. J., and Kerville, S. P. (2006). Photosynthetic responses of seven tropical seagrasses to elevated seawater temperature. J. Exp. Mar. Biol. Ecol. 330, 455-468. doi: 10.1016/j.jembe.2005.09.017
Collier, C. J., and Waycott, M. (2014). Temperature extremes reduce seagrass growth and induce mortality. Mar. Pollut. Bull. 83, 483-490. doi: 10.1016/j.marpolbul.2014.03.050

Cullen-Unsworth, L., and Unsworth, R. (2013). Seagrass meadows, ecosystem services, and sustainability. Environ. Sci. Policy Sust. Dev. 55, 14-28. doi: 10.1080/00139157.2013.785864

Cullen-Unsworth, L. C., Nordlund, L. M., Paddock, J., Baker, S., McKenzie, L. J., and Unsworth, R. K. (2014). Seagrass meadows globally as a coupled socialecological system: implications for human wellbeing. Mar. Pollut. Bull. 83, 387-397. doi: 10.1016/j.marpolbul.2013.06.001

De los Santos, C. B., Onoda, Y., Vergara, J. J., Pérez-Lloréns, J. L., Bouma, T. J., La Nafie, Y. A., et al. (2016). A comprehensive analysis of mechanical and morphological traits in temperate and tropical seagrass species. Mar. Ecol. Prog. Ser. 551, 81-94. doi: 10.3354/meps 11717

Delefosse, M., Povidisa, K., Poncet, D., Kristensen, E., and Olesen, B. (2016). Variation in size and chemical composition of seeds from the seagrass Zostera marina-ecological implications. Aquat. Bot. 131, 7-14. doi: 10.1016/j.aquabot.2016.02.003

Diaz-Almela, E., Marbà, N., and Duarte, C. M. (2007). Consequences of mediterranean warming events in seagrass (Posidonia oceanica) flowering records. Glob. Change Biol. 13, 224-235. doi: 10.1111/j.1365-2486.2006.01260.x

Doney, S. C., Ruckelshaus, M., Duffy, J. E., Barry, P. B., Chan, F., English, C. A., et al. (2011). Climate change impacts on marine ecosystems. Annu. Rev. Mar. Sci. 4, 11-37. doi: 10.1146/annurev-marine-041911-111611

Duarte, C. M. (1991). Seagrass depth limits. Aquat. Bot. 40, 363-377. doi: 10.1016/0304-3770(91)90081-F

Duarte, C. M. (1995). Submerged aquatic vegetation in relation to different nutrient regimes. Ophelia 41, 87-112. doi: 10.1080/00785236.1995.104 22039

Duarte, C. M. (2000). Marine biodiversity and ecosystem services: an elusive link. J. Exp. Mar. Biol. Ecol. 250, 117-131. doi: 10.1016/S0022-0981(00)00194-5

Duarte, C. M. (2001). Encyclopedia of Biodiversity Vol. 1: Seagrasses. San Diego, CA: Academic Press.

Duarte, C. M., and Cebrián, J. (1996). The fate of marine autotrophic production. Limnol. Oceanogr. 41, 1758-1766. doi: 10.4319/lo.1996.41.8.1758

Duarte, C. M., Uri, J. S., Agawin, N. S. R., Fortes, M. D., Vermaat, J. E., and Marbà, N. (1997). Flowering frequency of Philippine seagrasses. Bot. Mar. 40, 497-500. doi: 10.1515/botm.1997.40.1-6.497

Egea, L. G., Jiménez-Ramos, R., Hernández, I., and Brun, F. G. (2019). Effect of in situ short-term temperature increase on carbon metabolism and dissolved organic carbon (DOC) fluxes in a community dominated by the seagrass Cymodocea nodosa. PLoS ONE 14:e0210386. doi: 10.1371/journal.pone.0210386

Fonseca, M. S., Fourqurean, J. W., and Hoehl, M. A. R. (2019). Effect of seagrass on current speed: importance of flexibility vs. shoot density. Front. Mar. Sci. 6:376. doi: 10.3389/fmars.2019.00376

Fourqurean, J. W., Duarte, C. M., Kennedy, H., Marbà, N., Holmer, M., Mateo, M. A., et al. (2012). Seagrass ecosystems as a globally significant carbon stock. Nat. Geosci. 5, 505-509. doi: 10.1038/ngeo1477

Genty, B., Briantais, J. M., and Baker, N. R. (1989). The relationship between the quantum yield of photosynthetic electron transport and quenching of chlorophyll fluorescence. BBA Gen. Subjects 990, 87-92. doi: 10.1016/S0304-4165(89)80016-9

Glasby, T. M., Taylor, S. L., and Housefield, G. P. (2014). Factors influencing the growth of seagrass seedlings: a case study of Posidonia australis. Aquat. Bot. 120, 251-259. doi: 10.1016/j.aquabot.2014.09.003

González-Ortiz, V., Egea, L. G., Jiménez-Ramos, R., Moreno-Marín, F., Pérez-Lloréns, J. L., Bouma, T. J., et al. (2014). Interactions between seagrass complexity, hydrodynamic flow and biomixing alter food availability for associated filter-feeding organisms. PLoS ONE 9:e104949. doi: 10.1371/journal.pone.0104949

Grasshoff, K., Kremling, K., and Ehrhardt, M. (1999). Methods of Seawater Analysis. New York; Chichester; Brisbane; Singapore; Toronto: Wiley-VCH.

Gu, R., Zhou, Y., Song, X., Xu, S., Zhang, X., Lin, H., et al. (2018). Effects of temperature and salinity on Ruppia sinensis seed germination, seedling establishment, and seedling growth. Mar. Pollut. Bull. 134, 177-185. doi: 10.1016/j.marpolbul.2017.08.013 
Guerrero-Meseguer, L., Marín, A., and Sanz-Lázaro, C. (2017). Future heat waves due to climate change threaten the survival of Posidonia oceanica seedlings. Environ. Pollut. 230, 40-45. doi: 10.1016/j.envpol.2017.06.039

Gunderson, A. R., Armstrong, E. J., and Stillman, J. H. (2016). Multiple stressors in a changing world: the need for an improved perspective on physiological responses to the dynamic marine environment. Annu. Rev. Mar. Sci. 8, 357-378. doi: 10.1146/annurev-marine-122414-033953

Heck K. L. Jr., Pennock, J. R., Valentine, J. F., Coen, L. D., and Sklenar, S. A. (2000). Effects of nutrient enrichment and small predator density on seagrass ecosystems: an experimental assessment. Limnol. Oceanogr. 45, 1041-1057. doi: 10.4319/lo.2000.45.5.1041

Hemminga, M. A., and Duarte, C. M. (2000). Seagrass Ecology. Cambridge, UK: Cambridge University Press.

Hemminga, M. A., Harrison, P. G., and van Lent, F. (1991). The balance of nutrient losses and gains in seagrass meadows. Mar. Ecol. Prog. Ser. 71, 85-96. doi: 10.3354/meps071085

Hernán, G., Castejón, I., Terrados, J., and Tomas, F. (2019). Herbivory and resource availability shift plant defense and herbivore feeding choice in a seagrass system. Oecologia 189, 719-732. doi: 10.1007/s00442-019-04364-6

Hernán, G., Ortega, M. J., Gándara, A. M., Castejón, I., Terrados, J., and Tomas, F. (2017). Future warmer seas: increased stress and susceptibility to grazing in seedlings of a marine habitat-forming species. Global Change Biol. 23, 4530-4543. doi: 10.1111/gcb.13768

Hernán, G., Ramajo, L., Basso, L., Delgado, A., Terrados, J., Duarte, C. M., et al. (2016). Seagrass (Posidonia oceanica) seedlings in a high- $\mathrm{CO}_{2}$ world: from physiology to herbivory. Sci. Rep. 6:38017. doi: 10.1038/srep38017

Huber, S. C., and Israel, D. W. (1982). Biochemical basis for partitioning of photosynthetically fixed carbon between starch and sucrose in soybean (Glycine max Merr.) leaves. Plant Physiol. 69, 691-696. doi: 10.1104/pp.69.3.691

Invers, O., Kraemer, G. P., Pérez, M., and Romero, J. (2004). Effects of nitrogen addition on nitrogen metabolism and carbon reserves in the temperate seagrass Posidonia oceanica. J. Exp. Mar. Biol. Ecol. 303, 97-114. doi: 10.1016/j.jembe.2003.11.005

Jassby, A. D., and Platt, T. (1976). Mathematical formulation of the relationship between photosynthesis and light for phytoplankton. Limnol. Oceanogr. 21, 540-547. doi: 10.4319/lo.1976.21.4.0540

Jiang, Z., Huang, X., Zhang, J., Zhou, C., Lian, Z., and Ni, Z. (2014). The effects of air exposure on the desiccation rate and photosynthetic activity of Thalassia hemprichii and Enhalus acoroides. Mar. Biol. 161, 1051-1061. doi: 10.1007/s00227-014-2398-6

Jiménez, R., Egea, L. G., Vergara, J. J., Bouma, T. J., and Brun, F. G. (2019). The role of flow velocity combined with habitat complexity as a top-down regulator in seagrass meadows. Oikos 128, 64-76. doi: 10.1111/oik.05452

Jiménez-Ramos, R., Egea, L. G., Ortega, M. J., Hernández, I., Vergara, J. J., and Brun, F. G. (2017). Global and local disturbances interact to modify seagrass palatability. PLoS ONE 12:e0183256. doi: 10.1371/journal.pone.0183256

Kaldy, J. E. (2014). Effect of temperature and nutrient manipulations on eelgrass Zostera marina L. from the Pacific Northwest, USA. J. Exp. Mar. Biol. Ecol. 453, 108-115. doi: 10.1016/j.jembe.2013.12.020

Kegler, H. F., Hassenrück, C., Kegler, P., Jennerjahn, T. C., Lukman, M., Jompa, J., et al. (2018). Small tropical islands with dense human population: differences in water quality of near-shore waters are associated with distinct bacterial communities. PeerJ 6:e4555. doi: 10.7717/peerj.4555

Kennedy, P. G., Hausmann, N. J., Wenk, E. H., and Dawson, T. E. (2004). The importance of seed reserves for seedling performance: an integrated approach using morphological, physiological, and stable isotope techniques. Oecologia 141, 547-554. doi: 10.1007/s00442-004-1686-0

Khan, M. N., and Mohammad, F. (2014). "Eutrophication: challenges and solutions," in Eutrophication: Causes, Consequences And Control, eds A. Ansari and S. Gill (Dordrecht: Springer), 1-15.

Lee, K. S., Park, S. R., and Kim, Y. K. (2007). Effects of irradiance, temperature, and nutrients on growth dynamics of seagrasses: a review. J. Exp. Mar. Biol. Ecol. 350, 144-175. doi: 10.1016/j.jembe.2007.06.016

Lee, S. Y., Dunn, R. J. K., Young, R. A., Connolly, R. M., Dale, P. E. R., Dehayr, R., et al. (2006). Impact of urbanization on coastal wetland structure and function. Aust. Ecol. 31, 149-163. doi: 10.1111/j.1442-9993.2006.01581.x

Li, M., Lundquist, C. J., Pilditch, C. A., Rees, T. A. V., and Ellis, J. (2019). Implications of nutrient enrichment for the conservation and management of seagrass Zostera muelleri meadows. Aquat. Conserv. Mar. Freshw. Ecosyst. 29, 1484-1502. doi: 10.1002/aqc.3141

Macreadie, P. I., Anton, A., Raven, J. A., Beaumont, N., Connolly, R. M., Fries, E. A., et al. (2019). The future of blue carbon science. Nat. Commun. 10:3998. doi: 10.1038/s41467-019-11693-w

Manly, B. F. J. (1997). Randomization, Bootstrap and Monte Carlo Methods in Biology. London: Chapman and Hall.

Marbà, N., Duarte, C. M., Cebrián, J., Gallegos, M. E., Olesen, B., and SandJensen, K. (1996). Growth and population dynamics of Posidonia oceanica on the Spanish mediterranean coast: elucidating seagrass decline. Mar. Ecol. Prog. Ser. 137, 203-213. doi: 10.3354/meps137203

Marco-Méndez, C., Prado, P., and Sánchez-Lizaso, J. L. (2017). Epiphytes and nutrient contents influence Sarpa salpa herbivory on Caulerpa spp vs. seagrass species in Mediterranean meadows. Estuar. Coat. Mar. Sci. 184, 54-66. doi: 10.1016/j.ecss.2016.11.005

Martínez-Crego, B., Vergés, A., Alcoverro, T., and Romero, J. (2008). Selection of multiple seagrass indicators for environmental biomonitoring. Mar. Ecol. Prog. Ser. 361, 93-109. doi: 10.3354/meps07358

Masini, R. J., Anderson, P. K., and McComb, A. J. (2001). A Haloduledominated community in a subtropical embayment: physical environment, productivity, biomass, and impact of dugong grazing. Aquat. Bot. 71, 179-197. doi: 10.1016/S0304-3770(01)00181-4

McGlathery, K. J. (2001). Macroalgal blooms contribute to the decline of seagrass in nutrient-enriched coastal waters. J. Phycol. 37, 453-456. doi: 10.1046/j.1529-8817.2001.037004453.x

McMillan, C. (1984). The distribution of tropical seagrasses with relation to their tolerance of high temperatures. Aquat. Bot. 19, 369-379. doi: 10.1016/0304-3770(84)90049-4

Meysick, L., Infantes, E., and Boström, C. (2019). The influence of hydrodynamics and ecosystem engineers on eelgrass seed trapping. PLOS ONE 14:e0222020. doi: 10.1371/journal.pone.0222020

Moore, K. A., and Short, F. T. (2007). "Zostera: biology, ecology, and management," in Seagrasses: Biology, Ecology and Conservation, eds A. W. D. Larkum, R. J. Orth, and C. M. Duarte (Dordrecht: Springer), 361-386.

Moore, K. A., and Wetzel, R. L. (2000). Seasonal variations in eelgrass (Zostera marina L.) responses to nutrient enrichment and reduced light availability in experimental ecosystems. J. Exp. Mar. Biol. Ecol. 244, 1-28. doi: 10.1016/S0022-0981(99)00135-5

Moreno-Marín, F., Brun, F. G., and Pedersen, M. F. (2018). Additive responses to multiple environmental stressors in the seagrass Zostera marina. Limnol. Oceanogr. 63, 1528-1544. doi: 10.1002/lno.10789

Mvungi, E. F., and Pillay, D. (2019). Eutrophication overrides warming as a stressor for a temperate African seagrass (Zostera capensis). PloS ONE 14:e0215129. doi: 10.1371/journal.pone.0215129

Niu, S., Zhang, P., Liu, J., Guo, D., and Zhang, X. (2012). The effect of temperature on the survival, growth, photosynthesis, and respiration of young seedlings of eelgrass Zostera marina L. Aquaculture 350-353, 98-108. doi: 10.1016/j.aquaculture.2012.04.010

Nixon, S., Buckley, B., Granger, S., and Bintz, J. (2001). Responses of very shallow marine ecosystems to nutrient enrichment. Human Ecol. Risk Assess. 7, 1457-1481. doi: 10.1080/20018091095131

Oksanen, J., Blanchet, F. G., Friendly, M., Kindt, R., Legendre, P., McGlinn, D., et al. (2019). Vegan: Community Ecology Package. R package version 2.54. Available online at: https://CRAN.R-project.org/package=vegan (accessed February 25, 2020).

Ontoria, Y., Gonzalez-Guedes, E., Sanmartì, N., Bernardeau-Esteller, J., Ruiz, J. M., Romero, J., et al. (2019). Interactive effects of global warming and eutrophication on a fast-growing Mediterranean seagrass. Mar. Environ. Res. 145, 27-38. doi: 10.1016/j.marenvres.2019.02.002

Orth, R. J., Carruthers, T. J. B., Dennison, W. C., Duarte, C. M., Fourqurean, J. W., Heck, K. L., et al. (2006). A global crisis of seagrass ecosystems. BioScience 56, 987-996. doi: 10.1641/0006-3568(2006)56[987:AGCFSE]2.0.CO;2

Orth, R. J., Harwell, M. C., and Inglis, G. J. (2007). "Ecology of seagrass seeds and seagrass dispersal processes," in Seagrasses: Biology, Ecology and Conservation, eds A. W. D. Larkum, R. J. Orth, and C. M. Duarte (Dordrecht: Springer), 111-133.

Osland M. J., Day, R. H., Hall, C. T., Brumfield, M. D., Dugas, J. L., and Jones, W. R. (2016). Mangrove expansion and contraction at a poleward range limit: 
climate extremes and land-ocean temperature gradients. Ecology 98, 125-137. doi: $10.1002 /$ ecy. 1625

Paling, E. I., and McComb, A. J. (1994). Nitrogen and phosphorus uptake in seedlings of the seagrass Amphibolis antarctica in Western Australia. Hydrobiologia 294, 1-4. doi: 10.1007/BF00017618

Pereda-Briones, L., Terrados, J., and Tomas, F. (2019). Negative effects of warming on seagrass seedlings are not exacerbated by invasive algae. Mar. Pollut. Bull. 141, 36-45. doi: 10.1016/j.marpolbul.2019.01.049

Pereda-Briones, L., Tomas, F., and Terrados, J. (2018). Field transplantation of seagrass (Posidonia oceanica) seedlings: effects of invasive algae and nutrients. Mar. Pollut. Bull. 134, 160-165. doi: 10.1016/j.marpolbul.2017.09.034

Peterson, J. E., and Baldwin, A. H. (2004). Seedling emergence from seed banks of tidal freshwater wetlands: response to inundation and sedimentation. Aquat. Bot. 78, 243-254. doi: 10.1016/j.aquabot.2003.10.005

$\mathrm{R}$ Core Team (2019). R: A Language and Environment for Statistical Computing. $\mathrm{R}$ Foundation for Statistical Computing, Vienna. Available online at: http://www. R-project.org/

Roca, G., Alcoverro, T., Krause-Jensen, D., Balsby, T. J. S., van Katwijk, M. M., Marbà, N., et al. (2016). Response of seagrass indicators to shifts in environmental stressors: a global review and management synthesis. Ecol. Indic. 63, 310-323. doi: 10.1016/j.ecolind.2015.12.007

Sakshaug, E., Bricaud, A., Dandonneau, Y., Falkowski, P. G., Kiefer, D. A., Legendre, L., et al. (1997). Parameters of photosynthesis: definitions, theory and interpretation of results. J. Plankton Res. 19, 1637-1670. doi: 10.1093/plankt/19.11.1637

Schielzeth, H., and Nakagawa, S. (2013). Nested by design: model fitting and interpretation in a mixed model era. Methods Ecol. Evol. 4, 14-24. doi: 10.1111/j.2041-210x.2012.00251.x

Schupp, E. W. (1995). Seed-seedling conflicts, habitat choice, and patterns of plant recruitment. Am. J. Bot. 82, 399-409. doi: 10.1002/j.1537-2197.1995.tb 12645.x

Short, F., Carruthers, T., Dennison, W., and Waycott, M. (2007). Global seagrass distribution and diversity: a bioregional model. J. Exp. Mar. Biol. Ecol. 350, 3-20. doi: 10.1016/j.jembe.2007.06.012

Short, F. T. (1987). Effects of sediment nutrients on seagrasses: literature review and mesocosm experiment. Aquat. Bot. 27, 41-57. doi: 10.1016/0304-3770(87)90085-4

Short, F. T., Burdick, D. M., and Kaldy, III, J. E. (1995). Mesocosm experiments quantify the effects of eutrophication on eelgrass, Zostera marina. Limnol. Oceanogr. 40, 740-749. doi: 10.4319/lo.1995.40.4.0740

Short, F. T., and Duarte, C. M. (2001). "Methods for the measurement of seagrass growth and production," in Global Seagrass Research Methods, eds F. T. Short and R. G. Coles (Amsterdam: Elsevier Science SV), 155-198.

Short, F. T., and Neckles, H. A. (1999). The effects of global climate change on seagrasses. Aquat. Bot. 63, 169-196. doi: 10.1016/S0304-3770(98)00117-X

Short, F. T., and Wyllie-Echeverria, S. (1996). Natural and humaninduced disturbance of seagrasses. Environ. Conser. 23, 17-27. doi: $10.1017 /$ S0376892900038212

Silsbe, G., and Malkin, S. Y. (2015). Phytotools: Phytoplankton Production Tools. An R package available on CRAN.

Statton, J., Kendrick, G. A., Dixon, K. W., and Cambridge, M. L. (2014). Inorganic nutrient supplements constrain restoration potential of seedlings of the seagrass, Posidonia australis. Restor. Ecol. 22, 196-203. doi: 10.1111/rec. 12072

Teichberg, M., Wild, C., Bednarz, V. N., Kegler, H. F., Lukman, M., Gärdes, A. A., et al. (2018). Spatio-temporal patterns in coral reef communities of the spermonde archipelago, 2012-2014, I: comprehensive reef monitoring of water and benthic indicators reflect changes in reef health. Front. Mar. Sci. 5:33. doi: 10.3389/fmars.2018.00033

Terrados, J., Agawin, N. S., Duarte, C. M., Fortes, M. D., Kamp-Nielsen, L., and Borum, J. (1999a). Nutrient limitation of the tropical seagrass Enhalus acoroides (L.) royle in cape Bolinao, NW Philippines. Aquat. Bot. 65, 123-139. doi: 10.1016/S0304-3770(99)00036-4

Terrados, J., Duarte, C. M., Kamp-Nielsen, L., Agawin, N. S. R., Gacia, E., Lacap, D., et al. (1999b). Are seagrass growth and survival constrained by the reducing conditions of the sediment? Aquat. Bot. 65, 175-197. doi: 10.1016/S0304-3770(99)00039-X

Tewksbury, J. J., Huey, R. B., and Deutsch, C. A. (2008). Putting the heat on tropical animals. Science 320, 1296-1297. doi: 10.1126/science.1159328
Todgham, A. E., and Stillman, J. H. (2013). Physiological responses to shifts in multiple environmental stressors: relevance in a changing world. Integr. Comp. Biol. 53, 539-544. doi: 10.1093/icb/ict086

Tomás, F., Martínez-Crego, B., and Santos, R. (2015). Responses of seagrass to anthropogenic and natural disturbances do not equally translate to its consumers. Glob. Change Biol. 21, 4021-4030. doi: 10.1111/gcb.13024

Touchette, B. W., and Burkholder, J. M. (2002). Seasonal variations in carbon and nitrogen constituents in eelgrass (Zostera marina L.) as influenced by increased temperature and water-column nitrate. Bot. Mar. 45, 23-34. doi: 10.1515/BOT.2002.004

Touchette, B. W., and Burkholder, J. M. (2007). Carbon and nitrogen metabolism in the seagrass, Zostera marina L.: environmental control of enzymes involved in carbon allocation and nitrogen assimilation. J. Exp. Mar. Biol. Ecol. 350, 216-233. doi: 10.1016/j.jembe.2007.05.034

Touchette, B. W., Burkholder, J. M., and Glasgow, H. B. Jr. (2003). Variations in eelgrass (Zostera marina L.) morphology and internal nutrient composition as influenced by increased temperature and water column nitrate. Estuaries 26 , 142-155. doi: 10.1007/BF02691701

Tuya, F., Haroun, R., and Espino, F. (2014). Economic assessment of ecosystem services: monetary value of seagrass meadows for coastal fisheries. Ocean Coast. Manage. 96, 181-187. doi: 10.1016/j.ocecoaman.2014.04.032

Unsworth, R. K., Ambo-Rappe, R., Jones, B. L., La Nafie, Y. A., Irawan, A., Hernawan, U. E., et al. (2018). Indonesia's globally significant seagrass meadows are under widespread threat. Sci. Total Environ. 634, 279-286. doi: 10.1016/j.scitotenv.2018.03.315

Van Katwijk, M. M., Vergeer, L. H. T., Schmitz, G. H. W., and Roelofs, J. G. M. (1997). Ammonium toxicity in eelgrass Zostera marina. Mar. Ecol. Prog. Ser. 157, 159-173. doi: 10.3354/meps157159

Viana, I. G., Saavedra-Hortúa, D. A., Mtolera, M., and Teichberg, M. (2019). Different strategies of nitrogen acquisition in two tropical seagrasses from an oligotrophic environment. New Phytol. 223, 1217-1229. doi: $10.1111 / \mathrm{nph} .15885$

Waycott, M., Duarte, C. M., Carruthers, T. J., Orth, R. J., Dennison, W. C., Olyarnik, S., et al. (2009). Accelerating loss of seagrasses across the globe threatens coastal ecosystems. Proc. Natl. Acad. Sci. U.S.A. 106, 12377-12381. doi: 10.1073/pnas.0905620106

Weitzman, J. S., Zeller, R. B., Thomas, F. I. M., and Koseff, J. R. (2015). The attenuation of current- and wave-driven flow within submerged multispecific vegetative canopies. Limnol. Oceanogr. 60, 1855-1874. doi: 10.1002/lno.10121

Wernberg, T., Smale, D. A., and Thomsen, M. S. (2012). A decade of climate change experiments on marine organisms: procedure, patterns and problems. Glob. Change Biol. 18, 1491-1498. doi: 10.1111/j.1365-2486.2012.02656.x

Yemm, E. W., and Willis, A. (1954). The estimation of carbohydrates in plant extracts by anthrone. Biochem. J. 57, 508-514. doi: 10.1042/bj0570508

York, P. H., Gruber, R. K., Hill, R., Ralph, P. J., Booth, D. J., and Macreadie, P. I. (2013). Physiological and morphological responses of the temperate seagrass Zostera muelleri to multiple stressors: investigating the interactive effects of light and temperature. PLoS ONE 8:e76377. doi: 10.1371/journal.pone.0076377

Yue, S., Zhou, Y., Zhang, Y., Xu, S., Gu, R., Xu, S., et al. (2019). Effects of salinity and temperature on seed germination and seedling establishment in the endangered seagrass Zostera japonica Asch. \& Graebn. in northern China. Mar. Pollut. Bull. 146, 848-856. doi: 10.1016/j.marpolbul.2019.07.037

Zarranz, M. E., González-Henríquez, N., García-Jiménez, P., and Robaina, R. R. (2010). Restoration of Cymodocea nodosa (Uchria) Ascherson seagrass meadows through seed propagation: seed storage and influences of plant hormones and mineral nutrients on seedling growth in vitro. Bot. Mar 53, 439-448. doi: 10.1515/BOT.2010.051

Conflict of Interest: The authors declare that the research was conducted in the absence of any commercial or financial relationships that could be construed as a potential conflict of interest.

Copyright (๑) 2020 Artika, Ambo-Rappe, Teichberg, Moreira-Saporiti and Viana. This is an open-access article distributed under the terms of the Creative Commons Attribution License (CC BY). The use, distribution or reproduction in other forums is permitted, provided the original author $(s)$ and the copyright owner(s) are credited and that the original publication in this journal is cited, in accordance with accepted academic practice. No use, distribution or reproduction is permitted which does not comply with these terms. 